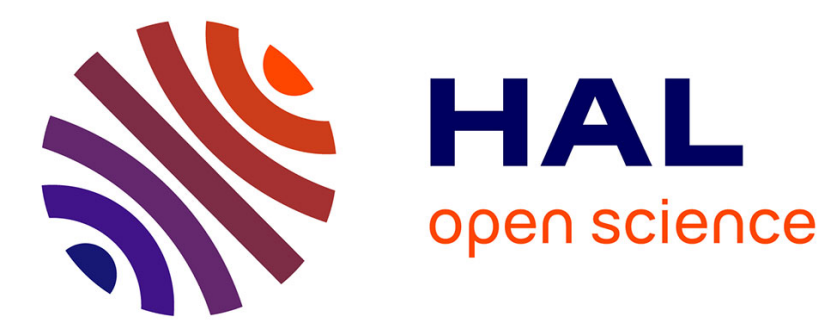

\title{
Impact of Holocene climate variability on lacustrine records and human settlements in South Greenland
}

Typhaine Guillemot, V Bichet, Anaëlle Simonneau, D Rius, C Massa, E Gauthier, H. Richard, Michel Magny

\section{- To cite this version:}

Typhaine Guillemot, V Bichet, Anaëlle Simonneau, D Rius, C Massa, et al.. Impact of Holocene climate variability on lacustrine records and human settlements in South Greenland. Climate of the Past Discussions, 2015, 11, pp.5401-5438. 10.5194/cpd-11-5401-2015 . insu-01240347

\section{HAL Id: insu-01240347 https://hal-insu.archives-ouvertes.fr/insu-01240347}

Submitted on 9 Dec 2015

HAL is a multi-disciplinary open access archive for the deposit and dissemination of scientific research documents, whether they are published or not. The documents may come from teaching and research institutions in France or abroad, or from public or private research centers.
L'archive ouverte pluridisciplinaire HAL, est destinée au dépôt et à la diffusion de documents scientifiques de niveau recherche, publiés ou non, émanant des établissements d'enseignement et de recherche français ou étrangers, des laboratoires publics ou privés. 


\section{Impact of Holocene climate variability on lacustrine records and human settlements in South Greenland}

T. Guillemot ${ }^{1}$, V. Bichet ${ }^{1}$, A. Simonneau ${ }^{2}$, D. Rius ${ }^{1}$, C. Massa ${ }^{1}$, E. Gauthier ${ }^{1}$, H. Richard ${ }^{1}$, and M. Magny ${ }^{1}$

${ }^{1}$ Université de Bourgogne/Franche-Comté, Laboratoire Chrono-environnement, CNRS UMR 6249,16 route de Gray 25030 Besançon, France

${ }^{2}$ Université d'Orléans, ISTO, CNRS UMR 7327, 1A rue de la Férollerie 45071 Orléans, France

Received: 16 October 2015 - Accepted: 4 November 2015 - Published: 17 November 2015

Correspondence to: T. Guillemot (typhaine.guillemot@univ-fcomte.fr)

Published by Copernicus Publications on behalf of the European Geosciences Union.
Impact of Holocene climate variability

T. Guillemot et al.

\section{Title Page}

\section{Abstract}

Introduction

Conclusions References

Tables

Figures

14

$\rightarrow 1$

4

Back

Close

Full Screen / Esc

Printer-friendly Version

Interactive Discussion

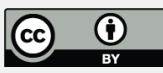




\section{Abstract}

Due to its sensitivity to climate changes, south Greenland is a particularly suitable area to study past global climate changes and their influence on locale Human settlements. A paleohydrological investigation was therefore carried out on two river-fed lakes: Lake

5 Qallimiut and Little Kangerluluup, both located close to the Labrador Sea in the historic farming center of Greenland. Two sediment cores (QAL-2011 and LKG-2011), spanning the last four millennia, were retrieved and showed similar thin laminae, described by high magnetic susceptibility and density, high titanium and TOC / TN atomic ratio, and coarse grain size. They are also characterized either by inverse grading followed by 10 normal grading or by normal grading only and a prevalence of red amorphous particles and lignocellulosic fragments, typical of flood deposits.

Flood events showed similar trend in both records: they mainly occurred during cooler and wetter periods characterized by weaker Greenlandic paleo-temperatures, substantial glacier advances, and a high precipitation on the Greenlandic Ice Sheet and

15 North Atlantic ice-rafting events. They can therefore be interpreted as a result of ice and snow-melting episodes. They occurred especially during rapid climate changes (RCC) such as the Middle to Late Holocene transition around $2250 \mathrm{BC}$, the Sub-boreal/Subatlantic transition around $700 \mathrm{BC}$ and the Little Ice Age (LIA) between AD 1300 and AD 1900, separated by cycles of 1500 years and driven by solar forcing. These global 20 RCC revealed by QAL-2011 and LKG-2011 flood events may have influenced Human settlements in south Greenland, especially the paleo-Eskimo cultures and the Norse settlement, and have been mainly responsible for their demise.

\section{Introduction}

The Holocene appears to be a steady climatic period in comparison with older glacial episodes, as climate evolution was not linear but showed several oscillations (O'Brien et al., 1995; Mayewski et al., 2004; D'Andrea et al., 2011; Larsen et al., 2012), result-

\section{CPD}

11, 5401-5438, 2015

Impact of Holocene climate variability

T. Guillemot et al.

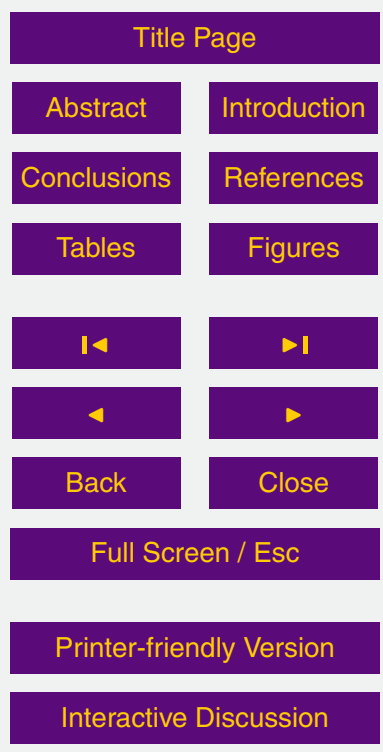

(i) 
ing from various forcing mechanisms such as solar activity (Bond et al., 2001; Magny, 2013) volcano emissions (Miller et al., 2012; Sigl et al., 2013) and/or ocean/atmosphere interactions (Hurrell and Denser, 2010; Knudsen et al., 2011). It is of prime importance to establish their spatial influence and phasing in order to understand natural climate 5 oscillations and their influence on past Human societies and thus to create better predictive climatic models. Indeed, even if current global warming is mainly the result of an anthropogenic pressure, the contribution of natural climate variability cannot be excluded and may explain the recent rapid rise in temperatures (Chylek et al., 2004; Solanki et al., 2004).

Projected climate scenarios predict a rise in surface temperature associated to an increase in the frequency and intensity of flood events in the coming decades (IPCC, 2013), especially in the Arctic region, which is very sensitive to climate changes (Serreze and Barry, 2011). Due to its proximity to the Greenlandic Ice Sheet (GIS), the polar front and the adjacent North Atlantic oceanic currents, south Greenland is a particularly 15 suitable area to record in natural archives past global climate changes and their associated forcing mechanisms at high resolution (Fig. 1a). While numerous proxy records have been used to infer past temperature in the Arctic (D'Andrea et al., 2011; McKay and Kaufman, 2014; Millet et al., 2014), few records have been used to infer past hydrological activity (Sundqvist et al., 2014) despite the extreme importance of hydrological conditions for Arctic ecosystems and their potential feedback on global climate (MacDonald et al., 2000).

To assess of past hydrological conditions during the Holocene, a sedimentological multiproxy approach was performed, compiling physical (magnetic susceptibility, density and grain size) and geochemical (X-ray fluorescence, X-ray diffraction, elemental analyses and organic geochemistry) measurements, on two lacustrine cores. They were retrieved from two river-fed lakes: Lake Qallimiut and Little Kangerluluup located between the GIS and the Labrador Sea in the Vatnahverfi, known as the archeological farming center of Greenland where two agropastoral phases settled (the Norse period between AD 986 and ca. AD 1450 and over the last century, since the 1920s). Thus,

\section{CPD}

11, 5401-5438, 2015

Impact of Holocene climate variability

T. Guillemot et al.

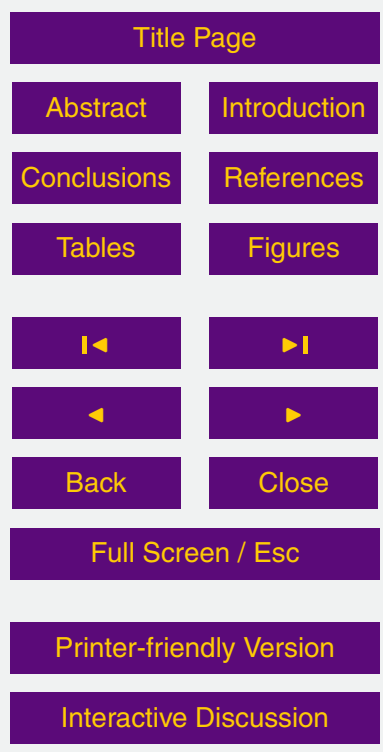

(1) 
this study reconstructs at high resolution the global climatic variations and the large scale drivers of Greenlandic climate though hydrological changes in lacustrine catchments that may have influenced past Human settlements (i.e. vulnerability, adaptation strategies, demise, etc...) during the last four millennia.

\section{Settings}

\subsection{Localization and climate}

The study area is located between the GIS and the Labrador Sea (Fig. 1a and b). Due to this geographical position, the local climate is mainly influenced by oceanic currents, such as cold polar waters $\left(<0^{\circ} \mathrm{C}\right)$ of the eastern Greenland current and warm waters $10\left(+4{ }^{\circ} \mathrm{C}\right)$ of the Irminger current, which mix to the west of Kap Farvel (Bond et al., 1997). The area is also windy with strong and relatively warm foehn winds blowing from the ice cap throughout the year, that are responsible for dryness. Meteorological data of the last 60 years are characteristic of a sub-oceanic climate, with a mean annual temperature of $0.9^{\circ} \mathrm{C}$, a yearly precipitation of $907 \mathrm{~mm}, 211$ days with frost and 61 days

\subsection{The Qallimiut lake system}

Lake Qallimiut $\left(60^{\circ} 43^{\prime} 27^{\prime \prime} \mathrm{N} ; 45^{\circ} 23^{\prime} 12^{\prime \prime} \mathrm{E} ; 40\right.$ ma.s.I.) is a proglacial lake located close to the hamlet of Qallimiut ca. $2 \mathrm{~km}$ to the south, near the Alluitsup Kangerlua fjord (Fig. 1c). It is aligned through a north-west/south-east axis with a surface of ca. 82 ha and a maximum depth of $26 \mathrm{~m}$. Two main tributaries feed it (on the north-west and the east shores respectively) while a single outlet drains it directly in the Alluitsup Kangerlua fjord (Fig. 1c). Its catchment, composed of granites (geological survey of Denmark and Greenland; http://www.geus.dk), has a surface of $112 \mathrm{~km}^{2}$ and a catchment to lake ratio around 137. It includes around twenty upstream lakes, making Lake Qallimiut the last sediment trap of this catchment (Fig. 1c). Less than ten ruins, dated from the Norse

\section{4}

\section{CPD}

$11,5401-5438,2015$

Impact of Holocene climate variability

T. Guillemot et al.

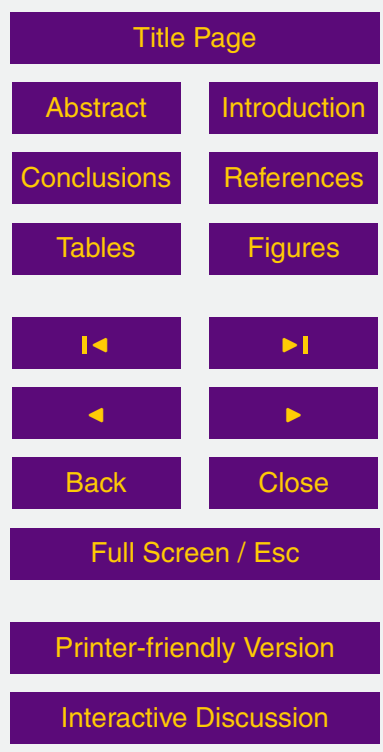


period, were inventoried in the catchment with only two sites directly found around the lake (Madsen et al., 2009). These two Norse archaeological sites have already been surveyed. Ruins group E77, a medium-sized farmstead, is located in the north-west part of the lake and was formerly excavated in AD 1880 (Holm, 1883; Madsen, 2014), 5 and ruins group E77a, near the coast, seems to be a large, highly eroded farmstead (Madsen, 2014). Nowadays, two recent farms can be found on the north and south shores of the lake (the largest one is located near the lake outlet).

\subsection{The Little Kangerluluup lake system}

Lake Little Kangerluluup $\left(60^{\circ} 38^{\prime} 32^{\prime \prime} \mathrm{N}\right.$; $45^{\circ} 38^{\prime} 11^{\prime \prime} \mathrm{E}$; 10 ma.s.I.) is also a proglacial lake, located close to Kangerluluup Qaqaa hill and Lake Kangerluluup, near the Torsukattak fjord (Fig. 1c). It is quite circular with a tiny surface of 6 ha and a maximum depth of $6.4 \mathrm{~m}$. Lake Little Kangerluluup is fed by only one major tributary and is drained directly into the Torsukattak fjord by one outlet (Fig. 1c). Like Lake Qallimiut, its catchment is composed of granites (geological survey of Denmark and Greenland; $15 \mathrm{http}: / / \mathrm{www}$. geus.dk). It has a relatively small area $\left(8 \mathrm{~km}^{2}\right)$ with a catchment to lake ratio of ca. 133, quite similar that of Lake Qallimiut. The lake catchment is aligned along a north-east/south-west axis with a very steep gradient slope, reaching 900 to $10 \mathrm{~m}$ within only $2 \mathrm{~km}$ (Fig. 1c). Unlike Lake Qallimiut, only one upstream lake flows into Lake Little Kangerluluup (Fig. 1c). Norse ruins (E178) are located on the isthmus of the 20 far side of the river and were surveyed by Madsen et al. (2009) and Madsen (2014). This large farmstead with barns, enclosures and irrigation systems, attests to agropastoral activities in the catchment during the Middle Ages. Nowadays, there are no farms around the lake, indicating that no human activities took place during the last century around Lake Little Kangerluluup and more generally, at the end of the Torsukattak fjord.

\section{CPD}

$11,5401-5438,2015$

Impact of Holocene climate variability

T. Guillemot et al.

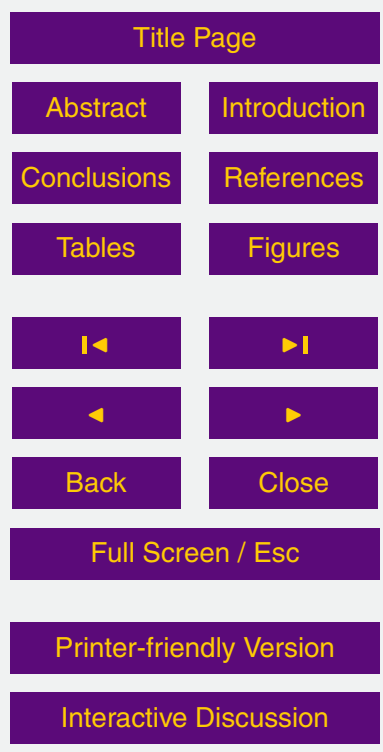




\subsection{Archaeological context}

Human occupation began around 2500 BC with the Saqqaq culture in the southern half of Greenland (Meldgaard, 2004; Jensen, 2009). These small populations of nomad hunters were replaced around $800 \mathrm{BC}$ by the sea-ice hunters of the Greenlandic Dorset

5 culture, who disappeared abruptly around 250 BC (Meldgaard, 2004; Jensen, 2009). Greenland remained unpopulated until the Norse colonization in 986 AD (Jones, 1986). This society, established during the medieval warm period (MWP), was mainly marked by agropastoral activities (Buckland et al., 2009; Arneborg et al., 2012; Guillemot et al., 2015) and ended around AD 1450 (Dugmore et al., 2009, 2012). The ancestors of the 10 modern Greenlandic, the Thule (neo-Eskimos), settled throughout Greenland around AD 1100 and still present today (Gulløv 1983, 2004). Due to recent global warming, sheep farming was established in the area by Danish in the 1920s (Austrheim et al., 2008). Several paleo-environmental studies revealed that farming by the Norse and during the last century, corresponding to the only two agropastoral phases in south 15 Greenland, had a strong impact on the ecosystems through vegetation changes (Gauthier et al., 2010; Schofield et al., 2011), soil erosion (Massa et al., 2012a) and changes in the lake trophic state (Perren et al., 2012; Millet et al., 2014).

\section{Materials and methods}

\subsection{Fieldwork}

In the deepest part of each lake basin (26 m for Lake Qallimiut and $6.4 \mathrm{~m}$ for Lake Little Kangerluluup), two cores were retrieved during the summer 2011: QAL-2011 $(118 \mathrm{~cm}$ long) and LKG-2011 (109.5 cm long), using a UWITEC gravity corer.

\section{CPD}

$11,5401-5438,2015$

Impact of Holocene climate variability

T. Guillemot et al.

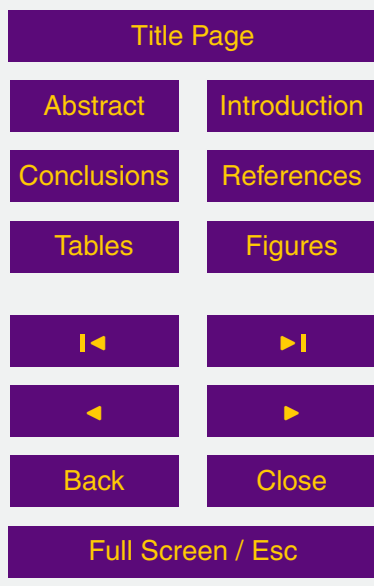

Printer-friendly Version

Interactive Discussion 


\subsection{Non-destructive laboratory analyses}

Initial core analyses of QAL-2011 and LKG-2011 included macroscopic description, digital photographs and X-ray radiographs (Scopix system, EPOC laboratory, University of Bordeaux, France), providing high-resolution imaging. X-ray radiographs are 5 based on 256 grey levels corresponding in value to X-ray densities (Migeon et al., 1998). $\gamma$-ray attenuation density and magnetic susceptibility (MS) measurements were performed with a GEOTEK multi-sensor core logger in a millimeter resolution (Chronoenvironnement laboratory, University of Bourgogne/Franche-Comté, France). Elementary analysis was performed with an X-ray microfluorescence core scanner (XRF, 10 AVAATECH system, EDYTEM laboratory, University of Savoie/Mont Blanc, France) at a resolution of $2 \mathrm{~mm}$ in two distinct runs. The first one, with a counting time of $20 \mathrm{~s}$ and a $10 \mathrm{kV}$ acceleration intensity, was followed by a second with a exposure time of $45 \mathrm{~s}$ and a $30 \mathrm{kV}$ acceleration intensity to obtain the relative abundance of elements from $\mathrm{Al}$ to $\mathrm{Bi}$. Titanium (Ti), a conservative element and a marker of detrital fluxes (Cohen, 15 2003; Arnaud et al., 2012), is expressed here in peak area counts. Usually, elements counts are normalized so as to correct drifts coming from variations in the water content or the grain size (Tjallingii et al., 2007; Revel et al., 2010). However, since the normalization of Ti by another chemical compound only smooths the Ti content trends, we used raw Ti counts directly in the present study. To determine the mineralogical composition of the sediment, X-ray diffraction (XRD) analyses were carried out in whole sediment using a D8 Advance Brucker diffractometer equipped with a LinxEye detector (Utinam laboratory, University of Bourgogne/Franche-Comté, France). The crumbled sediment is placed in the specimen holder where a step-scan of $0.5^{\circ}$ in the $2-52^{\circ}$ interval during a step time of $0.05 \mathrm{~s}$ is realized using a parallel beam geometry and CuK $\alpha$ 25 radiation at $1.54184 \AA$.

\section{CPD}

$11,5401-5438,2015$

Impact of Holocene climate variability

T. Guillemot et al.

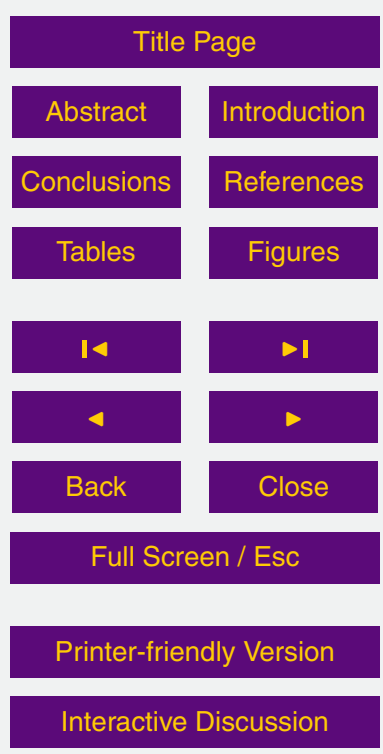




\subsection{Destructive analyses}

QAL-2011 and LKG-2011 were sampled every $0.5 \mathrm{~cm}$ slices, based on X-ray images in order to respect lithological boundaries and provide homogenous samples.

84 samples from QAL-2011 and 85 samples from LKG-2011 were therefore used for 5 grain size (GS) analyses, respectively. Around one $\mathrm{cm}^{3}$ of wet sediment was immersed in a solution of distilled water and hydrogen peroxide $\left(\mathrm{H}_{2} \mathrm{O}_{2}, 30 \%\right)$ to digest organic matter. Residual mineral fractions were then treated in an ultrasonic bath with a solution of sodium-hexametaphosphate to disperse aggregates. Finally, the GS of each sample was determined using a laser diffraction particle analyzer (LS230 Beckman-Coulter) 10 and represented by GS classes, according to granulometric scales $(<4,4-16,16-$ $63,>63 \mu \mathrm{m}$ ). Regions of interest (ROIs) for sedimentary micro-structure identification were selected based on the initial sedimentary description of the split cores as well as on the results of geophysical and geochemical core logging. The selected ROls cover sediment transitions, including larger laminae (at $32.2 \mathrm{~cm}$ in core QAL-2011 and 15 at $41.3 \mathrm{~cm}$ in core LKG-2011). Thin sections (one for each core) were sampled from these ROls and examined using a polarized light microscope.

Total carbon (TC), nitrogen (TN) and sulfur (TS) contents were measured on 161 and 187 selected samples, in QAL-2011 and LKG-2011 respectively, using a vario MAX CNS analyzer (Elementar). As the carbonate fraction was negligible in the sediments because of the Arctic climate and the granitic catchments, the total carbon measured corresponds to the total organic carbon (TOC). It was thus possible to access the relative contribution of lacustrine and terrestrial organic matter (OM) in the sediments via the TOC/TN atomic ratio (Meyers and Ishiwatari, 1993). To identify and quantify the composition of the organic fraction, quantitative organic petrography (QOP), developed by Graz et al. (2010), was performed on the ROls described above. After elimination of the mineral phases by hydrochloric and hydrofluoric attacks, particles were inventoried and counted according to their shape, color and reflectance using a transmitted and reflected light microscope (Combaz, 1964). Red amorphous particles (rAP), grey

\section{CPD}

11, 5401-5438, 2015

Impact of Holocene climate variability

T. Guillemot et al.

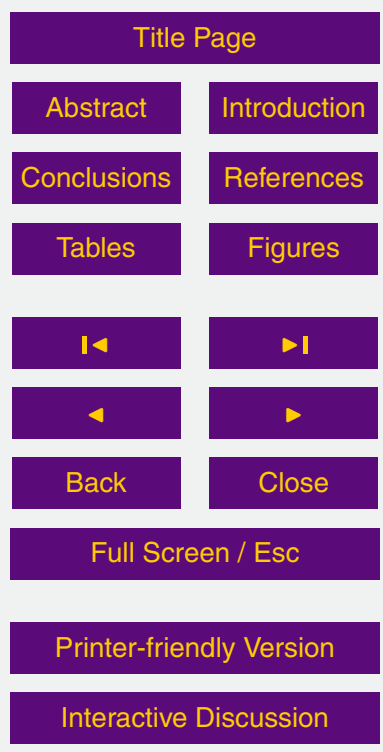


amorphous particles (gAP) and lignocellulosic fragments (LCF), in particular, were described following the classification frequently used in lake sediments (Simonneau et al., 2013a, b, 2014; Foucher et al., 2014).

\subsection{Core chronology}

5 The chronology of each core was based on six AMS radiocarbon datings of terrestrial plant macrofossils (Fig. 2a and b; Table 1a and b) conducted in the Lyon radiocarbon laboratory (Lyon, France) and Beta Analytics laboratory (Miami, United States). For the last 150 years, the chronologies of Qal-2011 and LKG-2011 were established thanks to short-lived radio-isotopes $\left({ }^{210} \mathrm{~Pb},{ }^{137} \mathrm{Cs},{ }^{241} \mathrm{Am}\right)$ measured by gamma spectrometry 10 in the underground laboratory in Modane (LSM-CNRS/CEA, France; Fig. 2a and b). Measurements were made on contiguous $0.5 \mathrm{~cm}$-thick samples of 0.8 to $1.7 \mathrm{~g}$ dried sediment, using a high efficiency, well-type Ge detector, during 24 to $72 \mathrm{~h}$ (deepest samples with lowest activities). The excess ${ }^{210} \mathrm{~Pb}$ (formed in the atmosphere by the decay of ${ }^{222} \mathrm{Rn}$ ) was calculated as the difference between the activities of total ${ }^{210} \mathrm{~Pb}$ 15 and ${ }^{226} \mathrm{Ra}$ (supported ${ }^{210} \mathrm{~Pb}$; Appleby, 2001). ${ }^{210} \mathrm{~Pb}$ chronology was derived for both lakes using the Constant Rate of Supply Model (CRS; Appleby and Oldfield, 1978). This type of model was chosen because it allows the sedimentation rate to vary. Results from radiocarbon and short-lived radio-isotopes were then combined with Clam (Blaauw, 2010) to produce two age-depth models using linear interpolation between 20 date points (Fig. 2a and b). The age-depth models were corrected for instantaneous flood event layers by subtracting the thickness of these layers before computation.
CPD

$11,5401-5438,2015$

Impact of Holocene climate variability

T. Guillemot et al.

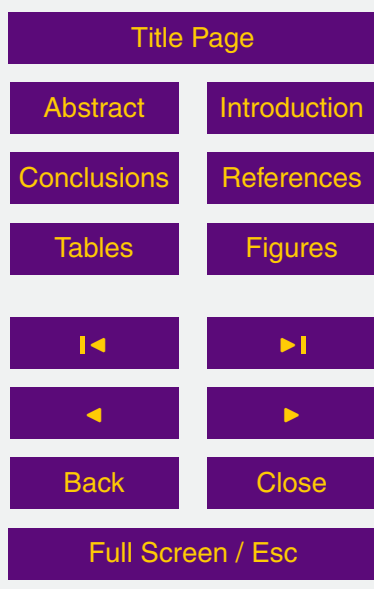

Printer-friendly Version

Interactive Discussion 


\section{Results}

\subsection{Chronology}

\section{Lake Qallimiut}

Core QAL-2011 covers the last four millennia. The age-depth model is quite linear 5 (Fig. 2a) and shows steps, especially in the first thirty $\mathrm{cm}$, due to an increased number of instantaneous events (see below, Sect. 5.1). The mean sediment accumulation rate (SAR) is $0.3 \mathrm{mmyear}^{-1}$ and the average age error is 160 years, not considering the extrapolated section of the model which is unconstrained by a radiocarbon date (below $90 \mathrm{~cm}$, in black dotted lines; Fig. 2a). The last century is contained in the top three $10 \mathrm{~cm}$, as indicated by the peak of ${ }^{137} \mathrm{Cs}$ between 1.5 and $2.5 \mathrm{~cm}$, corresponding to the maximum fallout consecutive to atmospheric nuclear weapon tests around AD 1963 (Fig. 2a).

\section{Lake Little Kangerlulup}

Similarly, the age-depth model of LKG-2011 covers the last four millennia. It is quite linear, shows several steps due to instantaneous events and has a mean SAR of $0.3 \mathrm{~mm}_{\text {year }}{ }^{-1}$ (Fig. 2b). A slight rise in the SAR up to $0.4 \mathrm{~mm}_{\text {year }}{ }^{-1}$ is recorded during the last millennium, which is not visible in the QAL-2011 age-depth model. The average age error of LKG-2011 age-depth model is ca. 200 years, not considering the extrapolated section of the model, below $90 \mathrm{~cm}$ (in black dotted lines; Fig. 2b). The last century is recorded in the first $4 \mathrm{~cm}$ with the AD 1963 peak of ${ }^{137} \mathrm{Cs}$ located at $2-2.5 \mathrm{~cm}$ (Fig. 2b).

Impact of Holocene climate variability

T. Guillemot et al.

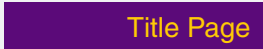




\subsection{Lithology, physical and chemical properties of the laminated facies}

\section{Lake Qallimiut}

Three stratigraphic units (SU1 to SU3) were identified in core QAL-2011 (Fig. 3a).

The first one (SU1, from 118 to $95 \mathrm{~cm}$ ) is characterized by a brownish silty sediment

5 (with a principal GS mode of ca. $30 \mu \mathrm{m}$, Fig. 3a) and interrupted by five thin white laminae closely spaced at 117, 113.9, 113.4, 110.4 and $100.9 \mathrm{~cm}$ (Table 2a). The MS is the only parameter that remains constant (around $100 \times 10^{-5}$ S.I.) all along SU1 (Fig. 3a). The density and the Ti content show a slight reduction at the base (from 1.3 to $1.1 \mathrm{~g} \mathrm{~cm}^{-3}$ for the density, and from 10000 to 9000 peak area for Ti, Fig. 3a) 10 whereas the TOC increases slightly (from 4 to $8 \%$; Fig. 3). Finally, the mean value of the TOC/TN is 13 (Fig. 3a).

The second stratigraphic unit (SU2, from 95 to $32.5 \mathrm{~cm}$ ) is the darker part of the QAL2011 sequence due to its higher organic carbon content (around $8 \%$ ). It is defined by a dark brown silty sediment (with a principal GS mode of $30 \mu \mathrm{m}$, Fig. 3) interrupted by 15 four white laminae at $81,77.2,66.8$ and $36.7 \mathrm{~cm}$ (Table 2a). As previously, MS values remain stable at ca. $100 \times 10^{-5}$ S.I. except for a peak at $66.8 \mathrm{~cm}$ (Fig. 3a). The density shows little variation around $1.1 \mathrm{~g} \mathrm{~cm}^{-3}$ (Fig. 3a). In spite of slight variations centered on the white laminae, the mean Ti and TOC contents, as well as the mean TOC/TN ratio, 9000 peak area, $8 \%$ and 13 respectively (Fig. 3a).

20 The last sedimentary unit (SU3, from $32.5 \mathrm{~cm}$ to the top of the sequence) is characterized by a light brown sandy silt sediment (with a principal GS mode twice as high as that of the other two SUs at ca. $60 \mu \mathrm{m}$, Fig. 3a). It is interrupted by a maximum of 18 white laminae spread all over SU3. These laminae generate abrupt shifts in all the measured parameters. MS rise to a mean value of $125 \times 10^{-5} \mathrm{~S}$.I., density, Ti content 25 and TOC/TN ratio also increase slightly to values of $1.2 \mathrm{~g} \mathrm{~cm}^{-3}, 10000$ peak area and 13.5, respectively (Fig. 3a), whereas TOC drops to $6 \%$ (Fig. 3).

The white laminae, present all along the QAL-2011 record, are globally infracentimetric, making naked-eye identification difficult in most cases (Table 2a). X-ray

Impact of Holocene climate variability

T. Guillemot et al.

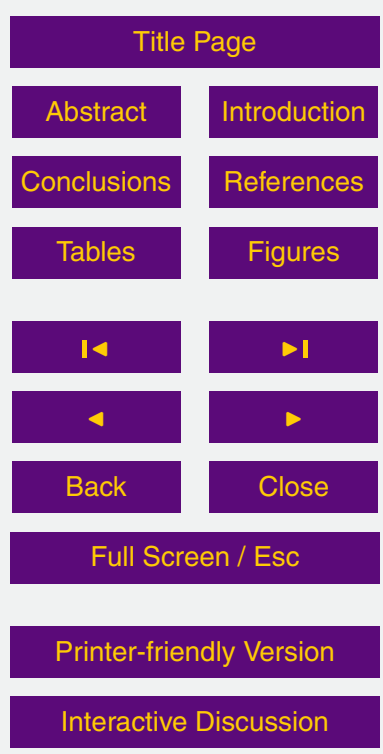


radiography is very helpful because the laminae are particularly well-defined in the high-resolution image, appearing in intense black, corresponding to high X-ray density values, whereas the background sediment is represented by light-grey color. Regardless of the SU, white laminae are characterized by higher MS (with a maximum value 5 of $450 \times 10^{-5} \mathrm{~S} . \mathrm{I}$. at $5 \mathrm{~cm}$, Fig. 3a), density (maximum value of $1.7 \mathrm{~g} \mathrm{~cm}^{-3}$, Fig. $3 \mathrm{a}$ ) and TOC/TN ratio (maximum value of 16, Fig. 3a). They are also rich in Ti (maximum value of 20000 peak area, Fig. 3a) and in coarse fraction (maximum value of $25 \%$ in the $>63 \mu \mathrm{m}$ massic class, Fig. 3a). Inversely, they are distinguished by much lower TOC (minimum value of $1.5 \%$, Fig. 3a). XRD tests indicated a similar mineralogical composition, composed of quartz, feldspaths and phyllosilicates, not different from the background sedimentation. The thicker lamina $(1.8 \mathrm{~cm}$ thick, between 32.2 and $34 \mathrm{~cm}$ ) showed a normal grading (fining upward, Fig. 3b) and was mainly composed of rAP and LCF, coming from soil and upper vegetation debris (Simonneau et al., 2013a), as part of other organic particles (Fig. 3b). On the basis of their similar physical and geo15 chemical properties, the results obtained on the thicker lamina were then extrapolated to the other laminae.

\section{Lake Little Kangerlulup}

Core LKG-2011 is also divided into three distinct stratigraphic units (SU1 to SU3, Fig. 4a).

20 The first one (SU1, from 108 to $74 \mathrm{~cm}$ ) is characterized by a light brown sandy silt background sediment (with a principal GS mode of $30 \mu \mathrm{m}$, Fig. 4a), interrupted by three thick brownish laminae (at 94.8, 81.6 and $79.7 \mathrm{~cm}$ ) and by two thin white laminae (at 107.7 and $104.9 \mathrm{~cm}$; Table $2 \mathrm{~b}$ ). MS values are much lower than in core QAL-2011, with background values of $10 \times 10^{-5} \mathrm{~S} . \mathrm{I}$ (10 times less than in SU1 in core QAL-2011, 25 Fig. 4a). Density, Ti content, TOC and TOC/TN ratio are quite similar to those observed in QAL-2011 SU1 (mean values of $1.2 \mathrm{~g} \mathrm{~cm}^{-3}, 6000$ counts, $7 \%$ and 14 , respectively, Fig. 4a).

\section{CPD}

$11,5401-5438,2015$

Impact of Holocene climate variability

T. Guillemot et al.

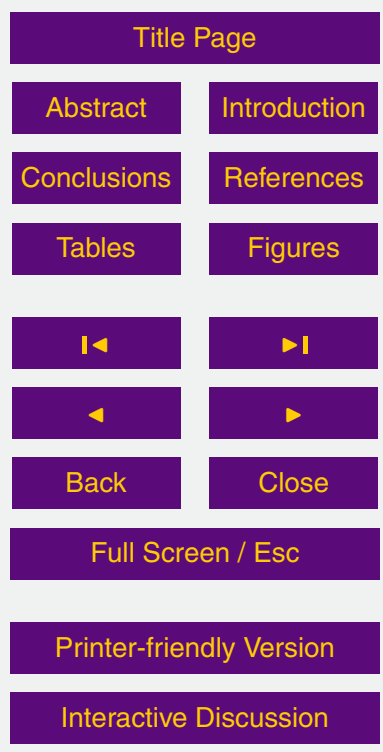


The second stratigraphic unit (SU2, from 74 to $51 \mathrm{~cm}$ ) is composed of a dark brown silty sediment with the same principal GS mode as SU1 (30 $\mu \mathrm{m}$, Fig. $4 \mathrm{a})$, and is not interrupted by any laminae. All the measured parameters are particularly steady: MS has a value of $5 \times 10^{-5} \mathrm{~S}$.I.; density, a value around $1.1 \mathrm{~g} \mathrm{~cm}^{-3}$; Ti content, a value of 56000 peak area; TOC, a mean value of $10 \%$ and TOC/TN ratio, a value around 14 (Fig. 4a).

The last sedimentary unit (SU3, from $51 \mathrm{~cm}$ to the top of the core) corresponds to the darker and coarse part of core LKG-2011 with a black sandy silt sediment and a principal GS mode of $50 \mu \mathrm{m}$ (Fig. 4a). Five thick dark grey laminae, only visible in 10 the X-ray radiographs, were identified at 49.2, 41.3, 29.2, 17, and $4 \mathrm{~cm}$ (Table $2 \mathrm{~b}$ ). The background MS value is $5 \times 10^{-5} \mathrm{~S}$.I. and density is $1.2 \mathrm{~g} \mathrm{~cm}^{-3}$ (Fig. 4a). There is also a pronounced rise in Ti content to 8000 peak area in SU3 (Fig. 4a). TOC has a background value around $9 \%$ and the TOC/TN ratio, a value of 14 (Fig. 4a).

Globally, the different types of laminae present within SU1 and SU3 (Table 2b), have 15 similar physical and geochemical characteristics (Fig. 4a). The brownish, light-grey and dark-grey laminae reach the highest values in MS (maximum value of $110 \times 10^{-5} \mathrm{~S} . \mathrm{I}$, Fig. 4a), density (maximum value of $1.7 \mathrm{~g} \mathrm{~cm}^{-3}$, Fig. $4 \mathrm{a}$ ), Ti content (maximum values of 15000 peak area, Fig. 4a), coarse fraction (maximum of $60 \%$ for the massic class $>63 \mu \mathrm{m}$, Fig. 4a) and TOC/TN ratio (maximum of 19, Fig. 4a). Laminae are also systematically marked by a strong decrease in TOC (minimum value of $3 \%$, Fig. 4a). XRD analyses conducted on these laminae showed a similar mineralogical composition composed of quartz, feldspaths and phyllosilicates, comparable to the background sedimentation. These physical and geochemical characteristics are similar to those observed within the laminae in core QAL-2011 (Fig. 3a), even if LKG-2011 laminae are larger ( $>1 \mathrm{~cm}$, Table $2 \mathrm{~b}$ ) than in QAL-2011. Moreover, the observations of the thinsections and the QOP analysis made on the brownish and dark-grey laminae from core LKG-2011, revealed the presence of an inversely graded bed followed by a normal one and the predominance of rAP and LCF in the OM content (Fig. 4b). On the basis of the

\section{CPD}

$11,5401-5438,2015$

Impact of Holocene

climate variability

T. Guillemot et al.

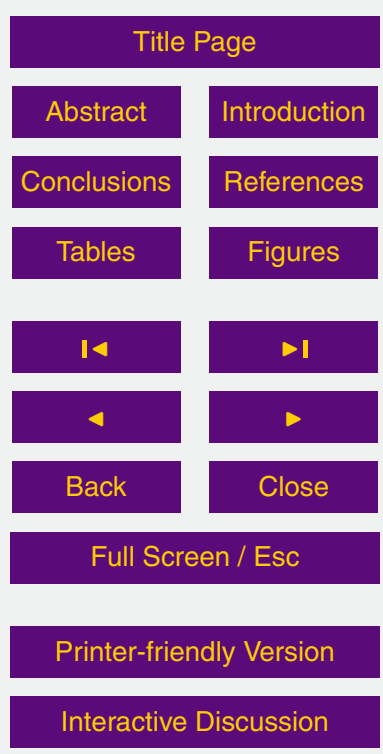

(1) 
similar physical and geochemical properties of LKG-2011 laminae, these results were extrapolated to other laminae.

\section{Discussion}

\subsection{Sedimentary events (SEs)}

5 The white laminae observed within core QAL-2011, as well as the brownish, lightgrey and dark-grey laminae within LKG-2011, showed similar sedimentological properties, clearly contrasting with the background sedimentation except for the mineralogical composition. Generally, they are characterized by high values of MS and density, higher Ti content and a rise in the massic class over $63 \mu \mathrm{m}$ (Figs. 3a-4a). All these 10 properties are characteristic of terrestrial inputs (Chapron et al., 2005; Arnaud et al., 2012). Moreover, the laminae composition from core QAL-2011 is also characterized by normal grading, high TOC/TN ratio, a predominance of rAP and LCF particles produced in soils (Fig. 3b; Di-Giovanni et al., 1998) and a mineralogical composition of granite, both resulting from the reworking of detrital inputs from the catchment area in

15 lake sediments (Simonneau et al., 2013a, b; Foucher et al., 2014). This organic signature therefore confirms the terrestrial origin of these laminae. Associated with the fining upward, both organic and granulometric results from core QAL-2011 are typical of hyperpycnal flood deposits (Mulder and Alexander, 2001; Simonneau et al., 2013a). The fining upward sequence can therefore be correlated to the falling limb of the flood hydrograph (Simonneau et al., 2013a). However, because Lake Qallimiut is the last sediment trap of the catchment with many lakes upstream, flood event records are thin and do not show the coarsening upward of the deposit, characteristic of the rising limb of the flood hydrograph (St-Onge et al., 2004). This suggests that the 27 white laminae described within core QAL-2011 can be related to exceptional hyperpycnal flood events associated with heavy rainfall and/or snowmelt events occurring all over the drainage basin and essentially reworking terrestrial materials.

\section{CPD}

$11,5401-5438,2015$

Impact of Holocene climate variability

T. Guillemot et al.

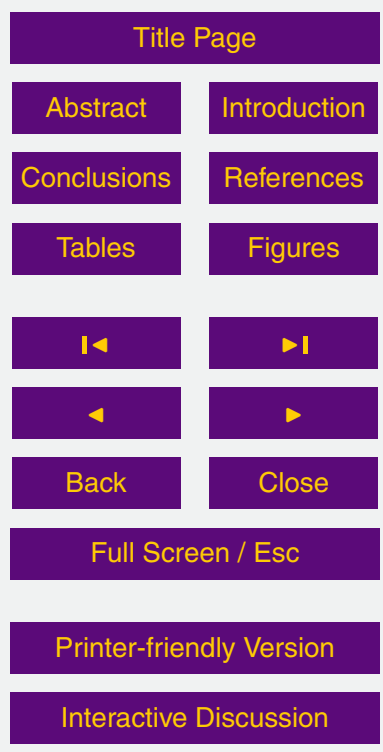

(1) 
Within core LKG-2011, thin-section and QOP analyses of the dark-grey and brownish laminae showed that the deposits are successively inversely and normally graded grain size, mainly constituted of rAP and LCF organic particles and composed of minerals present in granites (Fig. 4b). All these characteristics indicate that, as for core QAL5 2011, the 10 laminae described within core LKG-2011 (Table 2b) also correspond to hyperpycnal floods deposits too. Because there is only one lake upstream Lake Little Kangerluluup, and because of the elongated shape and the high gradient slope of its catchment with increases detrital inputs, the LKG-2011 flood event deposits are thicker and coarser than those identified within core QAL-2011.

\subsection{Flood frequencies during the Late Holocene}

Flood event records from both sites were smoothed over a 250 year moving window (K1D software, Gavin et al., 2006). QAL-2011 and LKG-2011 flood frequencies are globally synchronous during the last four millennia, considering age-depth models uncertainties (Fig. 5).

15 In more detail, a total of five high flood frequency periods were identified (Fig. 5; Table $2 a$ and $b$ ):

- between ca. $2300 \mathrm{BC}$ and ca. $1600 \mathrm{BC}$;

- between ca. $1100 \mathrm{BC}$ and ca. $900 \mathrm{BC}$;

- between ca. $600 \mathrm{BC}$ and ca. $200 \mathrm{BC}$;

- between ca. AD 1050 and ca. AD 1200;

- between ca. AD 1350 and ca. AD 1650.

These episodes of increased flood events are synchronous with low Greenlandic lake temperatures (correlated to the air temperatures; D'Andrea et al., 2011), Arctic glacier advances (Kelly et al., 2008; Briner et al., 2009, 2011; Larsen et al., 2011, 2012; Winsor et al., 2014) and North Atlantic ice-rafting events (Bond et al., 2001; Fig. 5). Thus, over 5415

\section{CPD}

$11,5401-5438,2015$

Impact of Holocene climate variability

T. Guillemot et al.
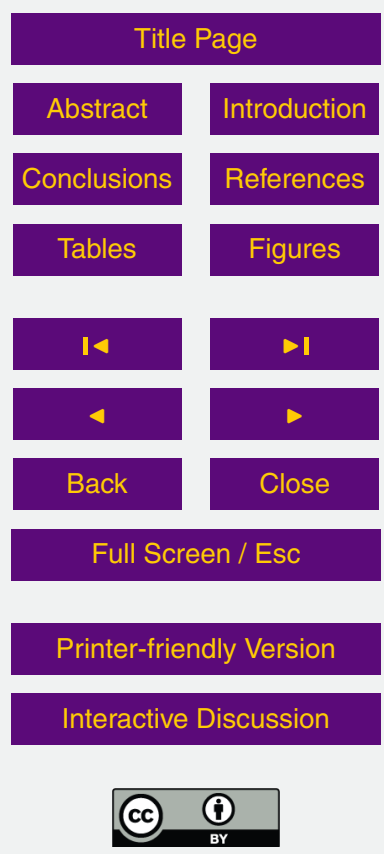
the second half of the Holocene, QAL-2011 and LKG-2011 flood deposits seemed to occur especially during cooler and wetter periods, associated to increased summer ice and snow-melting episodes. During colder and wetter periods, intense rainfall episodes created a sufficient stock of snow and ice. After short warming episodes in spring and 5 summer (such as several accumulated positive degree days or hot spell melt events caused by foehn winds), ice and snow melting events increased river discharge, sometimes inducing sporadic flood events (Mernild and Hasholt, 2009). In glacial areas, icemelting episodes might also be sometimes associated to the rupture of a glacier ice dam (Mayer and Schuler, 2005; Carrivick et al., 2013). In addition, high flood frequency 10 also appeared synchronously with weak solar irradiance phases (Bond et al., 1997, 2001; Steinhilber et al., 2009), probably suggesting a solar forcing for these events.

Four of the five Greenlandic flood-event phases were already defined at a global scale as rapid climate change periods (RCC) by Mayewski et al. (2004), separated by ca. 1500 year cycles and likely driven by the solar activity too (Bond et al., 1997, 2001; 15 Mayewski et al., 1997, 2004). For example, the period of high flood frequency between ca. $2300 \mathrm{BC}$ and ca. $1600 \mathrm{BC}$ may correspond to the Middle to Late Holocene transition (ca. $2250 \mathrm{BC}$ ), defined as a cooler period by Walker et al. (2012). Then, the period between ca. $1100 \mathrm{BC}$ and ca. $900 \mathrm{BC}$, as well as the one between $600 \mathrm{BC}$ and 200 BC, could match to the bipartite cooler Sub-boreal/Sub-atlantic transition (Van Geel et al., 1996; Martin-Puertas et al., 2012; Magny, 2013). Surprisingly, no flood events were recorded during the RCC corresponding to the Dark-Ages (DA) cooling (between ca. AD 200 and ca. AD 900; Bianchi and McCave, 1999; McDermott et al., 2001; Sicre et al., 2008). This could be explained by the fact that the DA was a drier climatic episode and/or it did not really impact the study area, especially the hydrological systems of Lake Qallimiut and Little Kangerluluup. Finally, the period between ca. AD 1000 and ca. AD 1650 revealed a maximum of flood deposits over the last four millennia, partly corresponding to the cooling of the Little Ice Age (LIA). With a maximum of flood events, the LIA cooling, occurring between AD 1300 and AD 1900, can be defined as the

\section{CPD}

$11,5401-5438,2015$

Impact of Holocene climate variability

T. Guillemot et al.

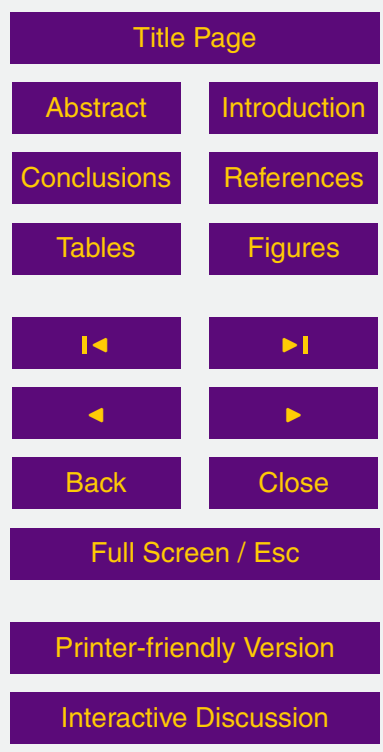

(1) 
main episode of climatic pejoration recorded in south-west Greenland over the Late Holocene.

\subsection{High-resolution flood frequency during the last 1000 years}

During the last millennium, flood events are especially recorded between ca. AD 1050 5 and AD 1200, and between AD 1350 and AD 1650 (Fig. 6).

The time interval between ca. AD 1350 and AD 1650 corresponds to the climatic pejoration of the LIA. A major decrease in Arctic temperatures (Sicre et al., 2008; Andrea et al., 2011; McKay and Kaufman, 2014; Millet et al., 2014; Figs. 5-6), a maximum of Arctic glacier advances (Kelly et al., 2008; Briner et al., 2009, 2011; Larsen et al., 2011, 10 2012; Winsor et al., 2014; Fig. 6), a maximum rate of ice accumulation (Andersen et al., 2006; Fig. 6) and a solar minimum (Spörer minimum; Bard et al., 2000; Fig. 6) were identified during this period, confirming that these flood events likely resulted from ice and snow-melting episodes and were potentially driven by solar forcing.

The highest flood frequency occurred between ca. AD 1050 and ca. AD 1200 dur15 ing the Oort solar minimum (Bard et al., 2000) and the Norse settlement (Arneborg et al., 2012; Fig. 6). It was the only time over four millennia that flood events took place during a warmer and drier period: the Medieval Warm Period (MWP; Andersen et al., 2006; McKay and Kaufman, 2014; Millet et al., 2014; Fig. 6). During this phase, flood deposits are thick (Fig. 6), attesting to the increase of detrital inputs probably induced by Norse farming activities in the lake watersheds. Indeed, around lakes Qallimiut and Little Kangerluluup, archaeological sites attested to agropastoral practices during the Norse settlement (Madsen et al., 2009; Madsen, 2014). They are likely responsible for enhancing the detrital inputs due to the reduction in the vegetation cover and to livestock trampling (Gauthier et al., 2010; Massa et al., 2012a), making the remobilization

of soil material easier during flood events and less intense hydrological events. Indeed a similar sedimentological response was observed, regardless of the intensity of the hydrological events, because of soil remobilization due to agropastoral activities in the catchment. The highest flood deposit thickness was recorded in Lake Little Kangerlu-

\section{CPD}

$11,5401-5438,2015$

Impact of Holocene climate variability

T. Guillemot et al.

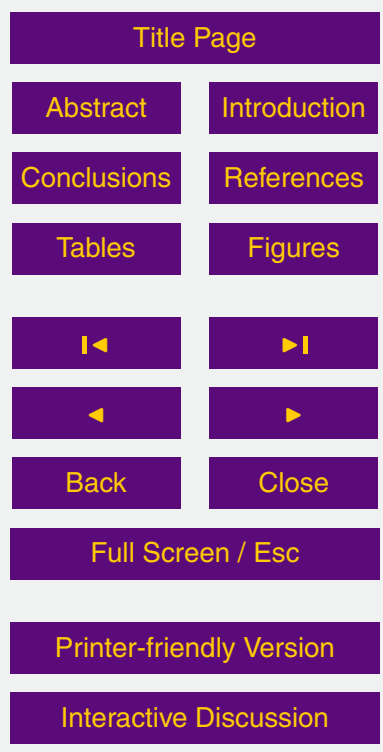


luup (Fig. 6), potentially explained by a larger number of archaeological sites identified around this lake (Madsen et al., 2009).

In south-west Greenland, there were two main agropastoral phases: the Norse settlement and the last century with higher impacts on ecosystems in recent decades (Massa 5 et al., 2012a). Thus, we can expect enhanced flood deposits in the last decades. However, thicker flood deposits occurred before the 1930s when the anthropogenic impacts were low (Massa et al., 2012a). It should be pointed out, though, that Lake Qallimiut and Little Kangerluluup are not proper lakes to trace recent agropastoral impacts since around Lake Qallimiut, few herds are grazing and the recent farm is located at its outlet 10 probably rejecting its effluents directly into the fjord. Concerning Lake Little Kangerluluup, there has been no human occupation or pastoral activities in the catchment during the last century (Madsen et al., 2009).

\subsection{Climatic influences on Human settlements}

A compilation of ca. 200 calibrated radiocarbon dates ( $2 \sigma$ ranges) from south Green15 land Norse sites was made (Arneborg, 2007; Edvardsson et al., 2007; Schofield et al., 2007; Arneborg et al., 2012; Walker et al., 2012; Ledger et al., 2013, 2014) to illustrate the patterns of occupation across time and especially its relative magnitude (Rick, 1987; Fig. 6). For example, a maximum of radiocarbon dates could reveal a period of maximum occupation (Kuzmin and Keates, 2005; Rick, 1987; Kuper and Kröpelin, 2006). Here, two periods of maximum occupation were therefore inventoried between AD 1000-AD 1100 and between AD 1250-AD 1350 (Fig. 6). From AD 850, the radiocarbon dates increased progressively until ca. AD 1050 because of the establishment of the settlement since AD 986. After ca. AD 1050, synchronously with a drop in radiocarbon dates, flood frequency rose, potentially indicating some short cooler and wetter

episodes during the MWP in spite of a global warm and dry trend. These periods are associated to a short demise of the Norse, recorded by a drop of radiocarbon dates, probably linked to these climatic perturbations. Radiocarbon age frequency rose again after ca. AD 1200 when flood events ceased, indicating repopulation by the Norse or

\section{CPD}

11, 5401-5438, 2015

Impact of Holocene climate variability

T. Guillemot et al.

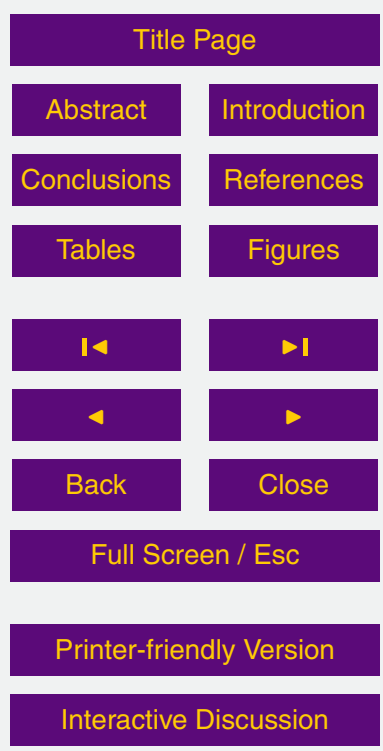


a renewal of their activities, possibly linked to the improvement in the climate. Around AD 1300, the maximum frequency of radiocarbon dates was synchronous with the peak of the estimated Norse population (Madsen, 2014). Radiocarbon dates fell to zero in AD 1450, with the progressive and definitive demise of the Norse settlement in Green5 land, approximately dating from the mid to late 15th century (Dugmore et al., 2009). This abandon is still a controversial issue (Barlow et al., 1997; Dugmore et al., 2012). However, it is generally assumed that the climatic deterioration played an important role in their abandon (D'Andrea et al., 2011; Massa et al., 2012a). Here, the radiocarbon dates decreased around AD 1300, synchronous with the beginning of the cooling of the 10 LIA and the second major rise in flood frequencies, supporting the idea of a progressive Norse demise mainly linked to the climatic deterioration of the LIA.

Global cooler and wetter episodes, revealed by the flood frequency within core QAL2011 and LKG-2011, revealed a potential impact on the Norse settlement. However, they were not the only society present in south Greenland during the last four millen15 nia. The paleo-Eskimo culture named the Saqqaq, established from ca. $2500 \mathrm{BC}$ to $850 \mathrm{BC}$, experienced cold and warm episodes during their settlement (D'Andrea et al., 2011; Fig. 5), showing a global adaptation to climate changes. For example, technological tool changes and inventions were observed around 1450 BC (Møbjerg, 1999), possibly revealing an adaptation to climate change (Sørensen, 2010), as this period corresponds to a solar minima phase (Steinhilber et al., 2009), characterized by cold temperatures (D'Andrea et al., 2011), an increase in North-Atlantic ice-rafted debris (Bond et al., 2001) and high flood frequencies (Fig. 5), potentially related to the beginning of the Sub-boreal/Sub-atlantic transition. Globally, the Saqqaq were defined as open water hunters (Meldgaard, 2004) in response to the relatively warm temperature trend occurring during their settlement (Moros et al., 2006; D'Andrea et al., 2011; Fig. 5). Thus, when the greatest decrease in temperatures (D'Andrea et al., 2011), increase in North-Atlantic ice-rafted debris (Bond et al., 2001) and south Greenlandic glacier advances (Kelly et al., 2008; Larsen et al., 2011, 2012; Winsor et al., 2014; Fig. 5) occurred at the end of the Sub-boreal/Sub-atlantic transition around 850 BC,

\section{CPD}

$11,5401-5438,2015$

Impact of Holocene climate variability

T. Guillemot et al.

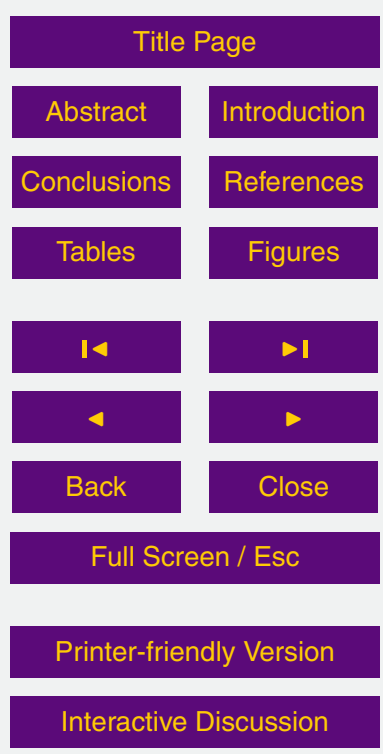

(i) 
they disappeared abruptly. Contemporary to their abandon, the Greenlandic Dorset, defined as sea-ice hunters because of their equipment (sledge shoes, soapstone vessels for burning seal fat and snow knives; Jensen, 2009) settled in Greenland. At the beginning of the Roman climate warming (RCW) when sea-ice cover diminished (Mo5 ros et al., 2006; Sicre et al., 2008; D'Andrea et al., 2011), the Dorset, who were illadjusted to warm conditions, left Greenland around 50 BC (Jensen, 2009). Finally, the Thule culture, present from the 12th century in Greenland, did not seem to be especially affected by the LIA. They just migrated in response to this cooler event and did not modify their diet or their tools, allowing them a long-term persistence in Greenland 10 (Sørensen, 2010).

Thus, the RCC, occurring during the second half of the Holocene and recorded through QAL-2011 and LKG-2011 flood deposits, seem to have influenced Greenlandic Human occupation since the first colonization in ca. $2500 \mathrm{BC}$.

\section{Conclusion}

15 To reconstruct past Holocene climatic variations in south-west Greenland, a multiproxy study was performed on two lacustrine cores retrieved from Lake Qallimiut and Lake Little Kangerluluup, covering the last four millennia (QAL-2011 and LKG-2011). This study, including physical (magnetic susceptibility, density and grain size) and geochemical (X-ray microfluorescence, elemental analyses and organic petrography) analysis, 20 has evidenced a total of 37 flood events in both sequences. They fall into five distinct phases: between $2300 \mathrm{BC}$ and $1600 \mathrm{BC}, 1100 \mathrm{BC}-900 \mathrm{BC} ; 600 \mathrm{BC}-200 \mathrm{BC}$; $A D$ 1050-AD 1200; $A D$ 1350-AD 1900 synchronous with high negative temperature anomalies, global glacier advances and an increase North-Atlantic in ice-rafted debris. High flood frequencies probably resulting from ice and snow-melting, coincide with so-

ar minima and could be matched with global RCC such as the Middle to Late Holocene transition (ca. $2250 \mathrm{BC}$ ), the Sub-boreal/Sub-atlantic transition (ca. $700 \mathrm{BC}$ ) and the LIA (from ca. AD 1300 to ca. AD 1900). The RCC with a maximum of flood events

\section{CPD}

11, 5401-5438, 2015

Impact of Holocene climate variability

T. Guillemot et al.

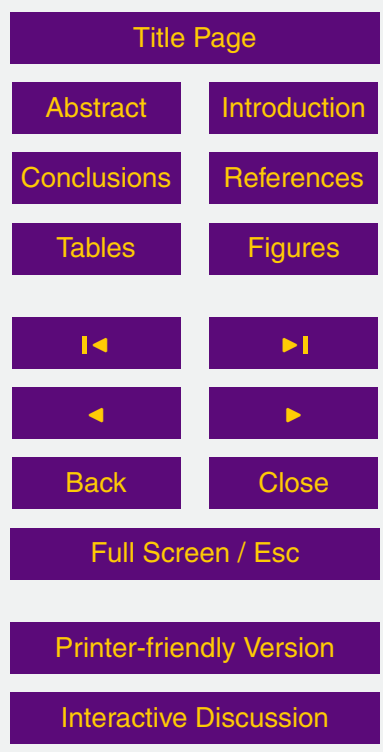

(i) 
recorded was the LIA, suggesting major climate deterioration in south Greenland at this time. Climatic deterioration revealed by QAL-2011 and LKG-2011 flood deposits may have potentially impacted local Human societies. Indeed, the Sub-boreal/Sub-atlantic transition might be responsible for the demise of the Saqqaq and the colonization of the 5 Dorset. Moreover, the climatic deterioration of the LIA, marked by two major successive rises in flood frequencies, seems to be one of the main reasons for the Norse abandon, illustrated by the radiocarbon dates frequency measured in archaeological sites. Lakes Qallimiut and Little Kangerluluup are proper sites to reconstruct past climate changes during the last four millennia and their impact on past Human societies except during 10 the Middle Ages, when Norse agropastoral activities enhanced the detrital inputs and disturbed their sedimentological responses.

\section{The Supplement related to this article is available online at doi:10.5194/cpd-11-5401-2015-supplement.}

Acknowledgements. This work received financial support from the University of 15 Bourgogne/Franche-Comté, the CNRS, the French Polar Institute (IPEV) and the ANR CEP\&S "Green Greenland" Project (ANR-10-CEPL-0008). We want to thank particularly Christophe Mavon for the ${ }^{210} \mathrm{~Pb}$ and ${ }^{137} \mathrm{Cs}$ analyses and the OREAS project for funding. We also thank Maxime Mermet for the Geotek multi-sensor core logger analyses, Marguerite Perrey for her help with the grain size analyses, Delphine Charpentier for the XRD analyses 20 and Bianca Perren for her assistance in the field. We also thank Marielle Hatton for her help with the preparation of QOP analysis in the ISTO laboratory.

\section{References}

Andersen, K. K., Ditlevsen, P. D., Rasmussen, S. O., Clausen, H. B., Vinther, B. M., Johnsen, S. J., and Steffensen, J. P.: Retrieving a common accumulation record

\section{CPD}

$11,5401-5438,2015$

Impact of Holocene climate variability

T. Guillemot et al.

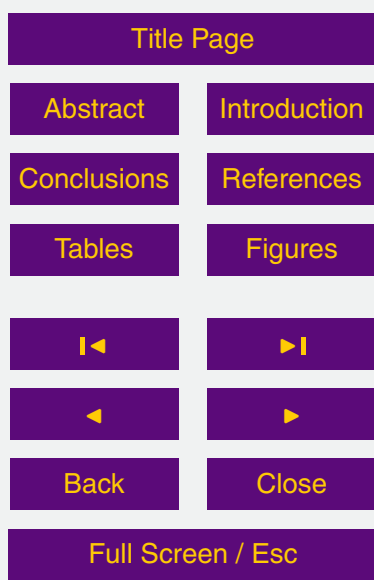

Printer-friendly Version

Interactive Discussion 
from Greenland ice cores for the past 1800 years, J. Geophys. Res., 111, D15106, doi:10.1029/2005JD006765, 2006.

Andresen, C. S., Björck, S., Bennike, O., and Bond, G.: Holocene climate changes in southern Greenland: evidence from lake sediments, J. Quaternary Sci., 19, 783-795, 2004.

5 Appleby, P. G.: Chronostratigraphic techniques in recent sediments, 171-203, in: Tracking Environmental Change Using Lake Sediments, Developments in PaleoEnvironmental Research, edited by: Last, W. M. and Smol, J. P., Springer Netherlands, 547 pp., 2001.

Appleby, P. G. and Oldfield, F.: The calculation of lead-210 dates assuming a constant rate of supply of unsupported ${ }^{210} \mathrm{~Pb}$ to the sediment, Catena, $5,1-8,1978$.

10 Arnaud, F., Révillon, S., Debret, M., Revel, M., Chapron, E., Jacob, J., Giguet-Covex, C., Poulenard, J., and Magny, M.: Lake Bourget regional erosion patterns reconstruction reveals Holocene NW European Alps soil evolution and paleohydrology, Quaternary Sci. Rev., 51, 81-92, 2012.

Arneborg, J.: Saga Trails. Brattahlid, Gardar, Hvalsey fjord's church and heljolfnesnes: four chieftain's framsteads in the north settlements of Greenland. A visitor's guidebook, The National Museum of Denmark, Copenhagen, 94 pp., 2007.

Arneborg, J., Lynnerup, N., and Heinemeier, J.: Human diet and subsistence patterns in Norse Greenland AD c. $980-A D$ c. 1450: archaeological interpretations, Journal of North Atlantic, 3, 119-133, 2012a.

20 Austrheim, G., Asheim, L.-J., Bjarnason, G., Feilberg, J., Fosaa, A. M., Holand, O., Hoegh, K., Jonsdottir, I. S., Magnusson, B., Mortensen, L. E., Mysterud, A., Olsen, E., Skonhoft, A., Steinheim, G., and Thorhallsdottir, A. G.: Sheep grazing in the North Atlantic region. A Long Term Perspective on Management, Resource Economy and Ecology, 3, Norges teknisknaturvitenskapelige universitet, 86 pp., 2008.

Bard, E., Raisbeck, G., Yiou, F., and Jouzel, J.: Solar irradiance during the last 1200 years based on cosmogenic nuclides, Tellus B, 52, 985-992, 2000.

Barlow, L. K., Sadler, J. P., Ogilvie, A. E. J., Buckland, P. C., Amorosi, T., Ingimundarson, J. H., Skidmore, P., Dugmore, A. J., and McGovern, T. H.: Interdisciplinary investigations of the end of the Norse western settlement in Greenland, Holocene, 7, 489-499, 1997.

30 Bianchi, G. G. and McCave, I. N.: Holocene periodicity in North Atlantic climate and deep-ocean flow south of Iceland, Nature, 397, 515-517, 1999.

Blaauw, M.: Methods and code for "classical" age-modelling of radiocarbon sequences, Quat. Geochronol., 5, 512-518, 2010.

\section{CPD}

$11,5401-5438,2015$

\section{Impact of Holocene climate variability}

T. Guillemot et al.

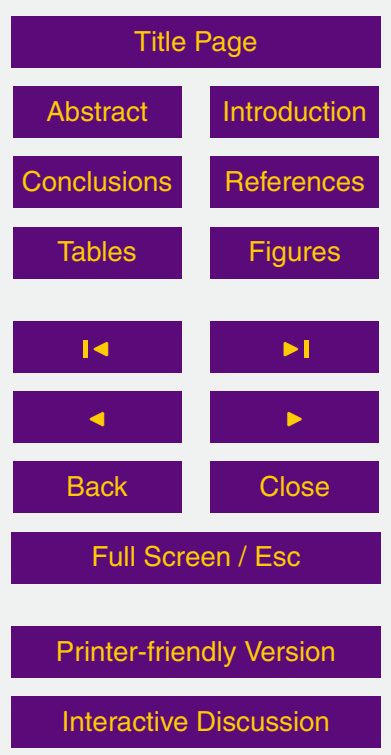

5422 
Bond, G., Showers, W., Cheseby, M., Lotti, R., Almasi, P., deMenocal, P., Priore, P., Cullen, H., Hajdas, I., and Bonani, G.: A pervasive millennial-scale cycle in North Atlantic Holocene and glacial climates, Science, 278, 1257-1266, 1997.

Bond, G., Kromer, B., Beer, J., Muscheler, R., Evans, M. N., Showers, W., Hoffmann, S., LottiBond, R., Hajdas, I., and Bonani, G.: Persistent solar influence on North Atlantic climate during the Holocene, Science, 294, 2130-2136, 2001.

Briner, J. P., Davis, P. T., and Miller, G. H.: Latest Pleistocene and Holocene glaciation of Baffin Island, Arctic Canada: key patterns and chronologies, Quaternary Sci. Rev., 28, 2075-2087, 2009.

10 Briner, J. P., Young, N. E., Thomas, E. K., Stewart, H. A. M., Losee, S., and Truex, S.: Varve and radiocarbon dating support the rapid advance of Jakobshavn Isbræ during the Little Ice Age, Quaternary Sci. Rev., 30, 2476-2486, 2011.

Buckland, P. C., Edwards, K. J., Panagiotakopulu, E., and Schofield, J. E.: Palaeoecological and historical evidence for manuring and irrigation at Garðar (Igaliku), Norse Eastern Settlement,

15 Greenland, Holocene, 19, 105-116, 2009.

Cappelen, J.: Weather Observations from Greenland 1958-2013. Observations Data with Description, DMI technical report No. 14-08, Danish Meteorological Institure, Copenhagen, 24 pp., 2014.

Cappelen, J., Jorgensen, B. V., Laursen, E. V., Stannius, L. S., and Thomsen, R. S.: The Observed Climate of Greenland with Climatological Standard Normals, 1961-1990, DMI technical report No. 00-18, Danish Meterorological Institute, Copenhagen, 152 pp., 2001.

Carrivick, J. L., Turner, A. G. D., Russell, A. J., Ingeman-Nielsen, T., and Yde, J. C.: Outburst flood evolution at Russell Glacier, western Greenland: effects of a bedrock channel cascade with intermediary lakes, Quaternary Sci. Rev., 67, 39-58, 2013.

Chapron, E., Arnaud, F., Noël, H., Revel, M., Desmet, M., and Perdereau, L.: Rhone River flood deposits in Lake Le Bourget: a proxy for Holocene environmental changes in the NW Alps, France, Boreas, 34, 404-416, 2005.

Chylek, P., Box, J. E., and Lesins, G.: Global warming and the Greenland ice sheet, Climate Change, 63, 201-221, 2004.

30 Cohen, A. S.: Paleolimnology: the History and Evolution of Lake Systems, Oxford University Press, USA, 2003.

Combaz, A.: Les palynofaciès, Revue de Micropaléontologie, 7, 205-218, 1964.

\section{CPD}

11, 5401-5438, 2015

Impact of Holocene climate variability

T. Guillemot et al.

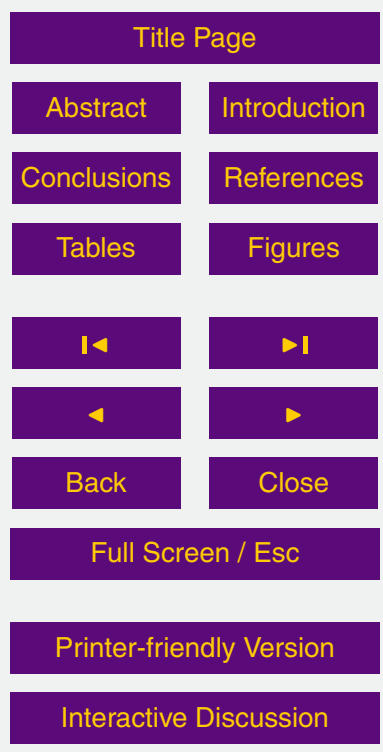


Dahl-Jensen, D., Mosegaard, K., Gundestrup, N., Clow, G. D., Johnsen, S. J., Hansen, A. W., and Balling, N.: Past temperatures directly from the Greenland ice sheet, Science, 282, 268$271,1998$.

D’Andrea, W. J., Huang, Y., Fritz, S. C., and Anderson, N. J.: Abrupt Holocene climate change as an important factor for human migration in West Greenland, P. Natl. Acad. Sci. USA, 108, 9765-9769, 2011.

Di-Giovanni, C., Disnar, J. R., Bichet, V., Campy, M., and Guillet, B.: Geochemical characterization of soil organic matter and variability of a postglacial detrital organic supply (Chaillexon Lake, France), Earth Surf. Proc. Land., 23, 1057-1069, 1998.

10 Dugmore, A. J., McGovern, T. H., Casely, A. F., and Smiarowski, K.: Norse Greenland settlement and limits to adaptation, in: Adaptating to Climate Change: Thresholds, Values, Governance, edited by: Adger, W. N., Lorenzi, I., and O’Brien, K. L., Cambridge University Press, Cambridge, 96-113, 2009.

Dugmore, A. J., McGovern, T. H., Vésteinsson, O., Arneborg, J., Streeter, R., and Keller, C.: 15 Cultural adaptation, compounding vulnerabilities and conjunctures in Norse Greenland, P. Natl. Acad. Sci. USA, 109, 3658-3663, 2012.

Edvardsson, R., Paulsen, C., Church, M., Simpson, I., Adderly, P., Palsdottir, A., and McGovern, T. H.: Archaeological Excavations at Qassiarsuk 2005-2006, field and data structure report 03-07, 108 pp., 2007.

20 Foucher, A., Salvador-Blanes, S., Evrard, O., Simonneau, A., Chapron, E., Courp, T., Cerdan, O., Lefèvre, I., Adriaensen, H., Lecompte, F., and Desmet, M.: Increase in soil erosion after agricultural intensification: evidence from a lowland basin in France, Anthropocene, 7 , 30-41, 2014.

Gauthier, E., Bichet, V., Massa, C., Petit, C., Vannière, B., and Richard, H.: Pollen and nonpollen palynomorph evidence of medieval farming activities in southwestern Greenland, Veg. Hist. Archaeobot., 19, 427-438, 2010.

Gavin, D. G., Hu, F. S., Lertzman, K., and Corbett, P.: Weak climatic control of stand-scale fire history during the late holocene, Ecology, 87, 1722-1732, 2006.

Graz, Y., Di-Giovanni, C., Copard, Y., Laggoun-Défarge, F., Boussafir, M., Lallier-Vergès, E., 30 Baillif, P., Perdereau, L., and Simonneau, A.: Quantitative palynofacies analysis as a new tool to study transfers of fossil organic matter in recent terrestrial environments, Int. J. Coal Geol., 84, 49-62, 2010.

\section{CPD}

11, 5401-5438, 2015

Impact of Holocene climate variability

T. Guillemot et al.

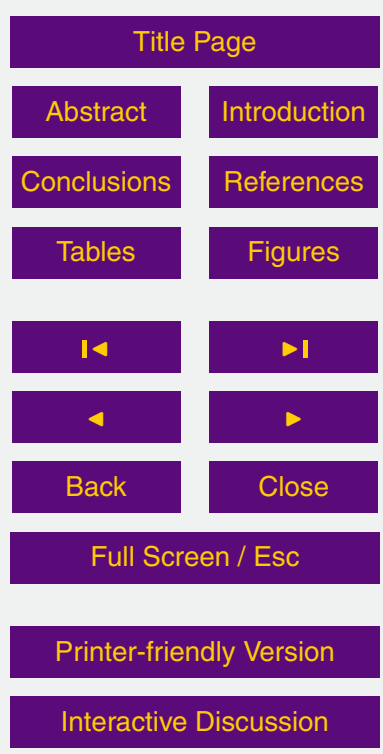

(1) 
Guillemot, T., Zocatelli, R., Bichet, V., Jacob, J., Gauthier, É., Massa, C., Le Milbeau, C., and Richard, $\mathrm{H}$.: Evolution of pastoralism in Southern Greenland during the last two millennia reconstructed from bile acids and coprophilous fungal spores in lacustrine sediments, Org. Geochem., 81, 40-44, 2015.

5 Gulløv, H. C.: Nuup kommuneani qangarnitsanik eqqaassutit inuit-kulturip nunaqarfii, Kalaallit Nunaata katersugaasivia and Nationalmuseet, 1983.

Gulløv, H. C.: Nunarput, vort land-Thule kulturen 1200-1900 e.v.t. 281-341, in: Grønlands forhistorie, edited by: Gulløv, H. C., København Gyldendal, 2004.

Holm, G.: Beskrivelse af ruiner i Julianehaabs distrikt, Meddelelser om Grønland, 6, 57-145, 1883.

Hurrell, J. W. and Deser, C.: North Atlantic climate variability: the role of the North Atlantic Oscillation, J. Marine Syst., 79, 231-244, 2010.

Jensen, J. F.: Stone Age of Qeqertarsuup Tunua (Disko Bugt): a regional analysis of the Saqqaq and Dorset cultures of Central West Greenland. Meddelelser om Grønland, Man and Society

15 32, Museum Tusculanum Press, 264 pp., 2009.

Jones, G.: The Norse Altlantic Saga, Oxford University press, New York, 1986.

Kaplan, M. R., Wolfe, A. P., and Miller, G. H.: Holocene environmental variability in Southern Greenland inferred from Lake Sediments, Quaternary Res., 58, 149-159, 2002.

Kelly, M. A., Lowell, T. V., Hall, B. L., Schaefer, J. M., Finkel, R. C., Goehring, B. M., Alley, R. B., and Denton, G. H.: A ${ }^{10} \mathrm{Be}$ chronology of lateglacial and Holocene mountain glaciation in the Scoresby Sund region, east Greenland: implications for seasonality during lateglacial time, Quaternary Sci. Rev., 27, 2273-2282, 2008.

Knudsen, M. F., Seidenkrantz, M.-S., Jacobsen, B. H., and Kuijpers, A.: Tracking the Atlantic Multidecadal Oscillation through the last 8000 years, Nat. Commun., 2, 178, doi:10.1038/ncomms1186, 2011.

Kuper, R. and Kröpelin, S.: Climate-controlled Holocene occupation in the Sahara: motor of Africa's evolution, Science, 313, 803-807, 2006.

Kuzmin, Y. V. and Keates, S. G.: Dates are not just data: paleolithic settlement patterns in Siberia derived from radiocarbon records, Am. Antiquity, 70, 773-789, 2005.

Larsen, D. J., Miller, G. H., Geirsdóttir, Á., and Ólafsdóttir, S.: Non-linear Holocene climate evolution in the North Atlantic: a high-resolution, multi-proxy record of glacier activity and environmental change from Hvítárvatn, central Iceland, Quaternary Sci. Rev., 39, 14-25, 2012.

\section{CPD}

11, 5401-5438, 2015

\section{Impact of Holocene climate variability}

T. Guillemot et al.

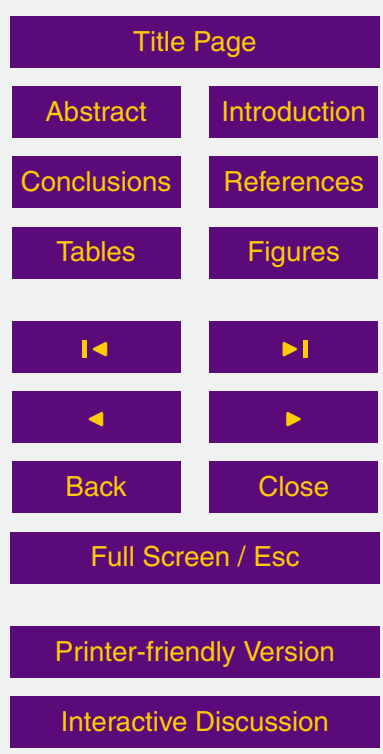


Larsen, N. K., Kjær, K. H., Olsen, J., Funder, S., Kjeldsen, K. K., and Nørgaard-Pedersen, N.: Restricted impact of Holocene climate variations on the southern Greenland ice sheet, Quaternary Sci. Rev., 30, 3171-3180, 2011.

Ledger, P. M., Edwards, K. J., and Schofield, J. E.: Shieling activity in the Norse Eastern settlement: palaeoenvironment of the "Mountain Farm", Vatnahverfi, Greenland, Holocene, 23, 810-822, 2013.

Ledger, P. M., Edwards, K. J., and Schofield, J. E.: Vatnahverfi: a green and pleasant land? Palaeoecological reconstructions of environmental and land-use change, Journal of the North Atlantic, 6, 29-46, 2014.

10 MacDonald, D. M. and Lamoureux, S. F.: Hydroclimatic and channel snowpack controls over suspended sediment and grain size transport in a High Arctic catchment, Earth Surf. Proc. Land., 34, 424-436, 2009.

Madsen, C. K.: Pastoral Settlement, Farming and Hierarchy in Norse Vatnahverfi, South Greenland, University of Copenhagen, 440 pp., 2014.

Madsen, C. K., Arneborg, J., Heide, P. B., and Smiarowski, K.: Norse Coastal Farms, field report in the Southwest Vatnahverfi Peninsula, Department of Danish Middle Age and Renaissance, Copenhagen, 96 pp., 2009.

Magny, M.: Orbital, ice-sheet, and possible solar forcing of Holocene lake-level fluctuations in west-central Europe: a comment on Bleicher, Holocene, 23, 1202-1212, 2013.

20 Martin-Puertas, C., Matthes, K., Brauer, A., Muscheler, R., Hansen, F., Petrick, C., Aldahan, A., Possnert, G., and van Geel, B.: Regional atmospheric circulation shifts induced by a grand solar minimum, Nat. Geosci., 5, 397-401, 2012.

Massa, C., Bichet, V., Gauthier, É., Perren, B. B., Mathieu, O., Petit, C., Monna, F., Giraudeau, J., Losno, R., and Richard, H.: A 2500 year record of natural and anthropogenic soil erosion in South Greenland, Quaternary Sci. Rev., 32, 119-130, 2012a.

Massa, C., Perren, B. B., Gauthier, É., Bichet, V., Petit, C., and Richard, H.: A multiproxy evaluation of Holocene environmental change from Lake Igaliku, South Greenland, J. Paleolimnol., 48, 241-258, 2012b.

Mayer, C. and Schuler, T. V.: Breaching of an ice dam at Qorlortossup tasia, South Greenland, Ann. Glaciol., 42, 297-302, 2005.

Mayewski, P. A., Meeker, L. D., Twickler, M. S., Whitlow, S., Yang, Q., Lyons, W. B., and Prentice, M.: Major features and forcing of high-latitude Northern Hemisphere atmospheric circu-
CPD

$11,5401-5438,2015$

Impact of Holocene climate variability

T. Guillemot et al.

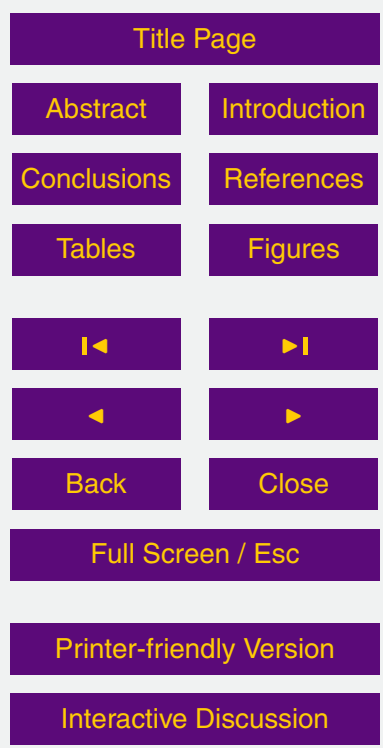


lation using a 110000 year-long glaciochemical series, J. Geophys. Res., 102, 26345-26366, 1997.

Mayewski, P. A., Rohling, E. E., Curt Stager, J., Karlén, W., Maasch, K. A., David Meeker, L., Meyerson, E. A., Gasse, F., van Kreveld, S., Holmgren, K., Lee-Thorp, J., Rosqvist, G.,

5 Rack, F., Staubwasser, M., Schneider, R. R., and Steig, E. J.: Holocene climate variability, Quaternary Res., 62, 243-255, 2004.

McKay, N. P. and Kaufman, D. S.: An extended Arctic proxy temperature database for the past 2000 years, Nature Scientific Data, doi:10.1038/sdata.2014.26, 2014.

Meldgaard, M.: Ancient Harp Seal Hunters of Disko Bay, Meddelelser om Grønland, Man and Society 30, Museum Tusculanum Press, 129 pp., 2004.

Mernild, S. H. and Hasholt, B.: Observed runoff, jökulhlaups and suspended sediment load from the Greenland Ice Sheet at Kangerlussuaq, West Greenland, 2007 and 2008, J. Glaciol., 55, 855-858, 2009.

Meyers, P. A. and Ishiwatari, R.: Lacustrine organic geochemistry - an overview of indicators 15 of organic matter sources and diagenesis in lake sediments, Org. Geochem., 20, 867-900, 1993.

Migeon, S., Weber, O., Faugeres, J.-C., and Saint-Paul, J.: SCOPIX: a new X-ray imaging system for core analysis, Geo-Mar. Lett., 18, 251-255, 1998.

Miller, G. H., Geirsdóttir, Á., Zhong, Y., Larsen, D. J., Otto-Bliesner, B. L., Holland, M. M., Bailey, D. A., Refsnider, K. A., Lehman, S. J., Southon, J. R., Anderson, C., Björnsson, H., and Thordarson, T.: Abrupt onset of the Little Ice Age triggered by volcanism and sustained by sea-ice/ocean feedbacks, Geophys. Res. Lett., 39, L02708, doi:10.1029/2011GL050168, 2012.

Millet, L., Massa, C., Bichet, V., Frossard, V., Belle, S., and Gauthier, E.: Anthropogenic vs. climatic control in a high-resolution 1500 year chironomid stratigraphy from a Southwestern Greenland lake, Quaternary Res., 81, 193-202, 2014.

Møbjerg, T.: New adaptive strategies in the Saqqaq culture of Greenland, ca. 1600-1400 BC, World Archaeol., 30, 452-465, 1999.

Moros, M., Jensen, K. G., and Kuijpers, A.: Mid-to late-Holocene hydrological and climatic variability in Disko Bugt, central West Greenland, Holocene, 16, 357-367, 2006.

Mulder, T. and Alexander, J.: The physical character of subaqueous sedimentary density flows and their deposits, Sedimentology, 48, 269-299, 2001.

CPD

$11,5401-5438,2015$

Impact of Holocene climate variability

T. Guillemot et al.

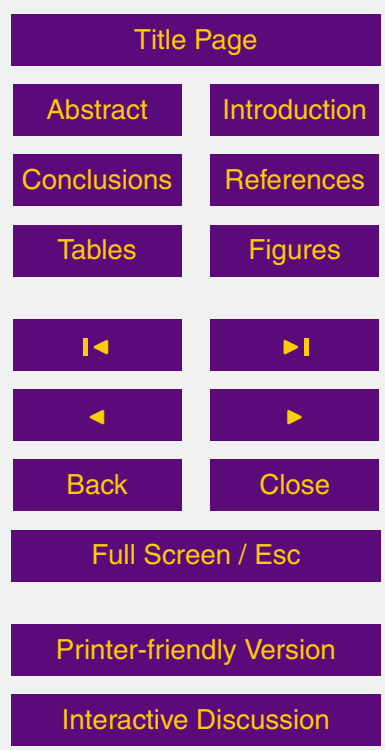


O’Brien, S. R., Mayewski, P. A., Meeker, L. D., Meese, D. A., Twickler, M. S., and Whitlow, S. I.: Complexity of Holocene climate as reconstructed from a Greenlandic ice core, Science, 270 , 1962-1964, 1995.

Perren, B. B., Massa, C., Gauthier, É., Bichet, V., Petit, C., and Richard, H.: A multiproxy evaluation of Holocene environmental change from Lake Igaliku, South Greenland, J. Paleolimnol., 48, 241-258, 2012.

Revel, M., Ducassou, E., Grousset, F. E., Bernasconi, S. M., Migeon, S., Revillon, S., Mascle, J., Murat, A., Zaragosi, S., and Bosch, D.: 100000 years of African monsoon variability recorded in sediments of the Nile margin, Quaternary Sci. Rev., 29, 1342-1362, 2010.

10 Rick, J. W.: Dates as data: an examination of the Peruvian preceramic radiocarbon record, Am. Antiquity, 52, 55-73, 1987.

Schofield, E. J., Edwards, K. and McMullen, J. A.: Modern pollen-vegetation relationships in subarctic Southern Greenland and the interpretation of fossil pollen data from the Norse landnám, J. Biogeogr., 34, 473-488, 2007.

Schofield, J. E. and Edwards, K. J.: Grazing impacts and woodland management in Eriksfjord: betula, coprophilous fungi and the Norse settlement of Greenland, Veg. Hist. Archaeobot., 20, 181-197, 2011.

Serreze, M. C. and Barry, R. G.: Processes and impacts of Arctic amplification: a research synthesis, Global Planet. Change, 77, 85-96, 2011.

20 Sicre, M.-A., Jacob, J., Ezat, U., Rousse, S., Kissel, C., Yiou, P., Eiríksson, J., Knudsen, K. L., Jansen, E., and Turon, J.-L.: Decadal variability of sea surface temperatures off North Iceland over the last 2000 years, Earth Planet. Sc. Lett., 268, 137-142, 2008.

Sigl, M., McConnell, J. R., Layman, L., Maselli, O., McGwire, K., Pasteris, D., Dahl-Jensen, D., Steffensen, J. P., Vinther, B., Edwards, R., Mulvaney, R., and Kipfstuhl, S.: A new bipolar ice core record of volcanism from WAIS Divide and NEEM and implications for climate forcing of the last 2000 years, J. Geophys. Res.-Atmos., 118, 1151-1169, 2013.

Simonneau, A., Chapron, E., Vannière, B., Wirth, S. B., Gilli, A., Di Giovanni, C., Anselmetti, F. S., Desmet, M., and Magny, M.: Mass-movement and flood-induced deposits in Lake Ledro, southern Alps, Italy: implications for Holocene palaeohydrology and natural hazards,

Simonneau, A., Doyen, E., Chapron, E., Millet, L., Vannière, B., Di Giovanni, C., Bossard, N., Tachikawa, K., Bard, E., Albéric, P., Desmet, M., Roux, G., Lajeunesse, P., Berger, J. F., and Arnaud, F.: Holocene land-use evolution and associated soil erosion in the French Prealps

CPD

$11,5401-5438,2015$

Impact of Holocene climate variability

T. Guillemot et al.

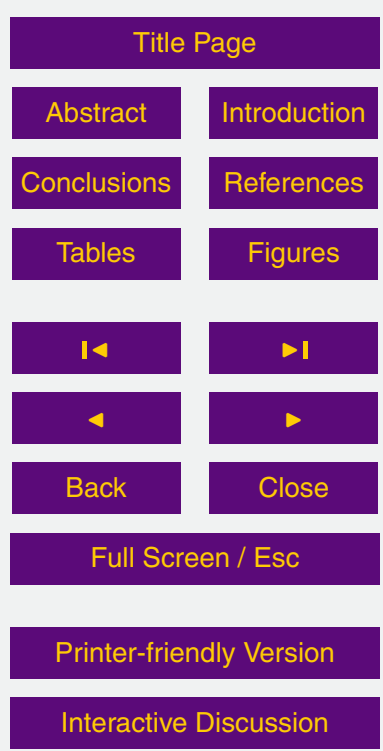

(1) 
inferred from Lake Paladru sediments and archaeological evidences, J. Archaeol. Sci., 40, 1636-1645, 2013b.

Simonneau, A., Chapron, E., Garçon, M., Winiarski, T., Graz, Y., Chauvel, C., Debret, M., Motelica-Heino, M., Desmet, M., and Di Giovanni, C.: Tracking Holocene glacial and highaltitude alpine environments fluctuations from minerogenic and organic markers in proglacial lake sediments (Lake Blanc Huez, Western French Alps), Quaternary Sci. Rev., 89, 27-43, 2014

Solanki, S. K., Usoskin, I. G., Kromer, B., Schüssler, M., and Beer, J.: Unusual activity of the Sun during recent decades compared to the previous 11000 years, Nature, 431, 1084-1087, 2004.

Sørensen, M.: Inuit landscape use and responses to climate change in the Wollaston Forland - Clavering Ø region, J. Geogr., 110, 155-174, 2010.

Steinhilber, F., Beer, J., and Fröhlich, C.: Total solar irradiance during the Holocene, Geophys. Res. Lett., 36, L19704, doi:10.1029/2009GL040142, 2009.

St-Onge, G., Mulder, T., Piper, D. J. W., Hillaire-Marcel, C., and Stoner, J. S.: Earthquake and flood-induced turbidites in the Saguenay Fjord (Québec): a Holocene paleoseismicity record, Quaternary Sci. Rev., 23, 283-294, 2004.

Sundqvist, H. S., Kaufman, D. S., McKay, N. P., Balascio, N. L., Briner, J. P., Cwynar, L. C., Sejrup, H. P., Seppä, H., Subetto, D. A., Andrews, J. T., Axford, Y., Bakke, J., Birks, H. J. B., Brooks, S. J., de Vernal, A., Jennings, A. E., Ljungqvist, F. C., Rühland, K. M., Saenger, C., Smol, J. P., and Viau, A. E.: Arctic Holocene proxy climate database - new approaches to assessing geochronological accuracy and encoding climate variables, Clim. Past, 10, 16051631, doi:10.5194/cp-10-1605-2014, 2014.

Tjallingii, R., Röhl, U., Kölling, M., and Bickert, T.: Influence of the water content on X-ray fluorescence core-scanning measurements in soft marine sediments, Geochem. Geophy. Geosy., 8, doi:10.1029/2006GC001393, 2007.

Van Geel, B., Buurman, J., and Waterbolk, H. T.: Archaeological and palaeoecological indications of an abrupt climate change in the Netherlands, and evidence for climatological teleconnections around 2650 BP, J. Quaternary Sci., 11, 451-460, 1996.

30 Walker, M. J. C., Berkelhammer, M., Björck, S., Cwynar, L. C., Fisher, D. A., Long, A. J., Lowe, J. J., Newnham, R. M., Rasmussen, S. O., and Weiss, H.: Formal subdivision of the Holocene series/epoch: a discussion paper by a working group of INTIMATE (Integration of

\section{CPD}

$11,5401-5438,2015$

\section{Impact of Holocene climate variability}

T. Guillemot et al.

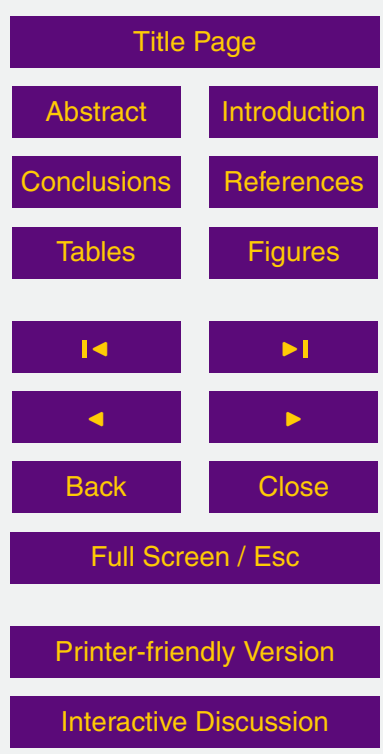


ice-core, marine and terrestrial records) and the subcommission on Quaternary stratigraphy (International Commission on Stratigraphy), J. Quaternary Sci., 27, 649-659, 2012.

Winsor, K., Carlson, A. E., and Rood, D. H.: ${ }^{10} \mathrm{Be}$ dating of the Narsarsuaq moraine in southernmost Greenland: evidence for a late-Holocene ice advance exceeding the Little Ice Age

\section{CPD}

$11,5401-5438,2015$

\section{Impact of Holocene climate variability}

T. Guillemot et al.

Title Page

Abstract

Introduction

Conclusions References

Tables

Figures

14

$\Delta$

4

Back

Close

Full Screen / Esc

Printer-friendly Version

Interactive Discussion

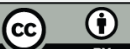


Table 1. Radiocarbon dates made on terrestrial remains and the age calibrations obtained from a linear model, using R program and the calibration curve of IntCal13 (Reimer, 2013). (a) Radiocarbon dates on Lake Qallimiut core. (b) Radiocarbon dates on Lake Little Kangerluluup core.

\begin{tabular}{lccccc}
\hline (a) Qallimiut & $\begin{array}{c}\text { Depth } \\
\text { cm }\end{array}$ & Material & $\begin{array}{c}\text { Radiocarbon ages } \\
\text { AD/BC }\end{array}$ & $\begin{array}{c}\text { Calibrated ages } \\
\text { AD/BC }\end{array}$ & Lab code \\
& 19.5 & wood & $1550 \pm 30$ & $1480 \pm 85$ & Beta-395567 \\
& 51.25 & wood & $240 \pm 30$ & $355 \pm 85$ & Beta-363187 \\
& 71.1 & wood & $-530 \pm 30$ & $-630 \pm 290$ & Lyon-9888 \\
& 88.4 & wood & $-1150 \pm 30$ & $-1355 \pm 145$ & Lyon-9889 \\
& 93.25 & wood & $-1425 \pm 30$ & $-1660 \pm 90$ & Lyon-9890 \\
& 95.75 & wood & $-1480 \pm 30$ & $-1720 \pm 120$ & Lyon-9891 \\
\hline (b) Little Kangerluluup & Depth & Material & Radiocarbon ages & Age AD calibré & Lab code \\
& cm & & AD/BC & AD/BC & \\
\hline & 20.55 & wood & $1705 \pm 30$ & $1655 \pm 50$ & Lyon-9885 \\
& 31.9 & wood & $1445 \pm 30$ & $1420 \pm 50$ & Lyon-9882 \\
& 34.5 & wood & $1345 \pm 30$ & $1335 \pm 75$ & Lyon-9886 \\
& 52.65 & wood & $735 \pm 30$ & $825 \pm 125$ & Lyon-9887 \\
77.75 & wood & $-165 \pm 30$ & $-125 \pm 155$ & Lyon-9883 \\
93.75 & wood & $-940 \pm 30$ & $-1060 \pm 140$ & Beta-386534 \\
\hline
\end{tabular}

CPD

$11,5401-5438,2015$

\section{Impact of Holocene climate variability}

T. Guillemot et al.

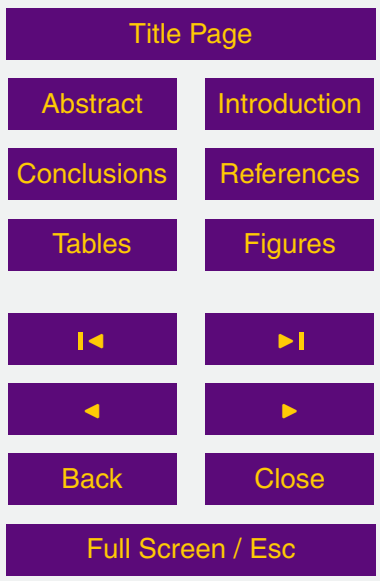

Printer-friendly Version

Interactive Discussion 
Table 2. Depth, thickness and age of the flood deposits. (a) Lake Qallimiut flood deposits description. (b) Lake Little Kangerluluup flood deposits description. NA indicates that the age error is not available because the end of the age-depth models is not constrained with a radiocarbon date.

\begin{tabular}{|c|c|c|c|c|c|}
\hline (a) Qallimiut & $\begin{array}{l}\text { Top } \\
\mathrm{cm}\end{array}$ & $\begin{array}{c}\text { Bottom } \\
\mathrm{cm}\end{array}$ & $\begin{array}{c}\text { Thickness } \\
\mathrm{cm}\end{array}$ & $\begin{array}{c}\text { Age } \\
\mathrm{AD} / \mathrm{BC}\end{array}$ & Age error \\
\hline & 1.4 & 1.9 & 0.5 & 1965 & 35 \\
\hline & 3.2 & 5.7 & 2.5 & 1904 & 150 \\
\hline & 7.5 & 8 & 0.5 & 1835 & 130 \\
\hline & 10.2 & 10.95 & 0.75 & 1755 & 125 \\
\hline & 15 & 15.5 & 0.5 & 1605 & 145 \\
\hline & 16.6 & 17 & 0.4 & 1565 & 155 \\
\hline & 17.5 & 17.75 & 0.25 & 1545 & 160 \\
\hline & 18.5 & 19.1 & 0.6 & 1515 & 170 \\
\hline & 21.8 & 21.95 & 0.15 & 1400 & 165 \\
\hline & 22.2 & 22.35 & 0.15 & 1390 & 160 \\
\hline & 23.3 & 23.9 & 0.6 & 1350 & 155 \\
\hline & 27.4 & 28 & 0.6 & 1195 & 150 \\
\hline & 29.5 & 29.6 & 0.1 & 1130 & 145 \\
\hline & 29.9 & 30.1 & 0.2 & 1125 & 145 \\
\hline & 30.2 & 30.4 & 0.2 & 1115 & 140 \\
\hline & 30.6 & 30.85 & 0.25 & 1110 & 140 \\
\hline & 31.8 & 32.05 & 0.25 & 1065 & 140 \\
\hline & 32.2 & 34 & 1.8 & 1055 & 140 \\
\hline & 36.7 & 37.2 & 0.5 & 940 & 135 \\
\hline & 66.8 & 67.8 & 1 & -465 & 255 \\
\hline & 77.2 & 77.7 & 0.5 & -905 & 200 \\
\hline & 81 & 81.5 & 0.5 & -1050 & 160 \\
\hline & 100.9 & 101.3 & 0.4 & -1885 & NA \\
\hline & 110.4 & 110.6 & 0.2 & -2145 & NA \\
\hline & 113.4 & 113.7 & 0.3 & -2225 & NA \\
\hline & 113.9 & 114.2 & 0.3 & -2230 & NA \\
\hline & 117 & 117.5 & 0.5 & -2310 & NA \\
\hline \multirow[t]{11}{*}{ (b) Little Kangerluluup } & $\begin{array}{l}\text { Top } \\
\mathrm{cm}\end{array}$ & $\begin{array}{c}\text { Bottom } \\
\mathrm{cm}\end{array}$ & $\begin{array}{c}\text { Thickness } \\
\mathrm{cm}\end{array}$ & $\begin{array}{c}\text { Age } \\
\text { AD/BC }\end{array}$ & Age error \\
\hline & 4 & 6 & 2 & 1930 & 210 \\
\hline & 17 & 19 & 2 & 1725 & 370 \\
\hline & 29.2 & 30.7 & 1.5 & 1455 & 115 \\
\hline & 41.3 & 44.1 & 2.8 & 1083 & 120 \\
\hline & 49.2 & 51 & 1.8 & 880 & 160 \\
\hline & 79.7 & 81.1 & 1.4 & -275 & 235 \\
\hline & 81.6 & 82.7 & 1.1 & -310 & 225 \\
\hline & 94.8 & 98.5 & 3.7 & -1140 & NA \\
\hline & 104.9 & 105.8 & 0.9 & -1580 & NA \\
\hline & 107.7 & 109 & 1.3 & -1715 & NA \\
\hline
\end{tabular}

\section{2}

\section{CPD}

$11,5401-5438,2015$

\section{Impact of Holocene climate variability}

T. Guillemot et al.

Title Page

Abstract

Introduction

Conclusions References

Tables

Figures

14

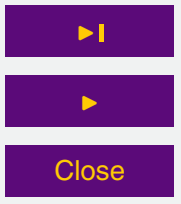

Back

Close

Full Screen / Esc

Printer-friendly Version

Interactive Discussion

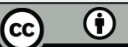




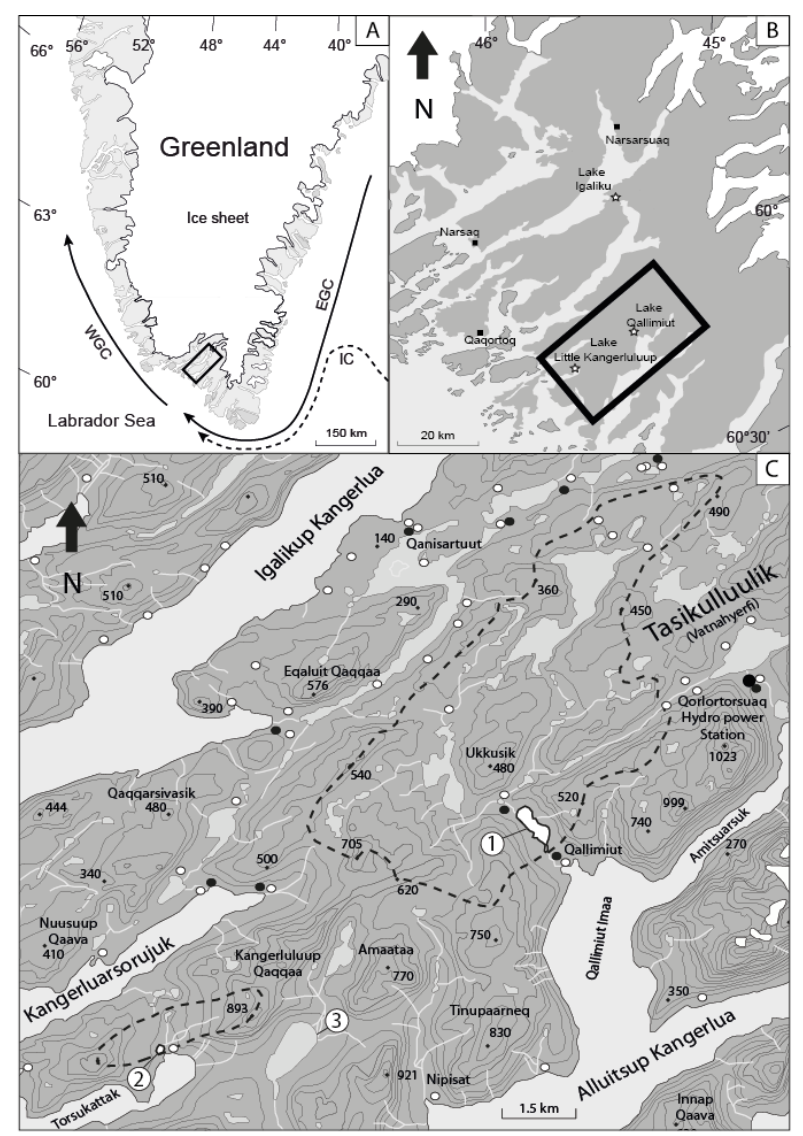

CPD

11, 5401-5438, 2015

\section{Impact of Holocene climate variability}

T. Guillemot et al.

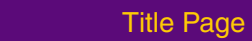

\section{Abstract}

Introduction

Conclusions References

Tables

Figures

\section{4}

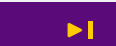

4

Back
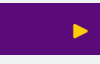

\section{Full Screen / Esc}

Printer-friendly Version

Figure 1. Localization of Lake Qallimiut and Little Kangerluluup. (a) Map of Greenland. (b) Map of South Greenland. (c) Catchments outlines (dotted black lines). White points represent Norse archeological sites and the black ones, recent farms. Number 1 indicates the location of Lake Qallimiut, number 2 matches Lake Little Kangerluluup and number 3, Lake Kangerluluup. 

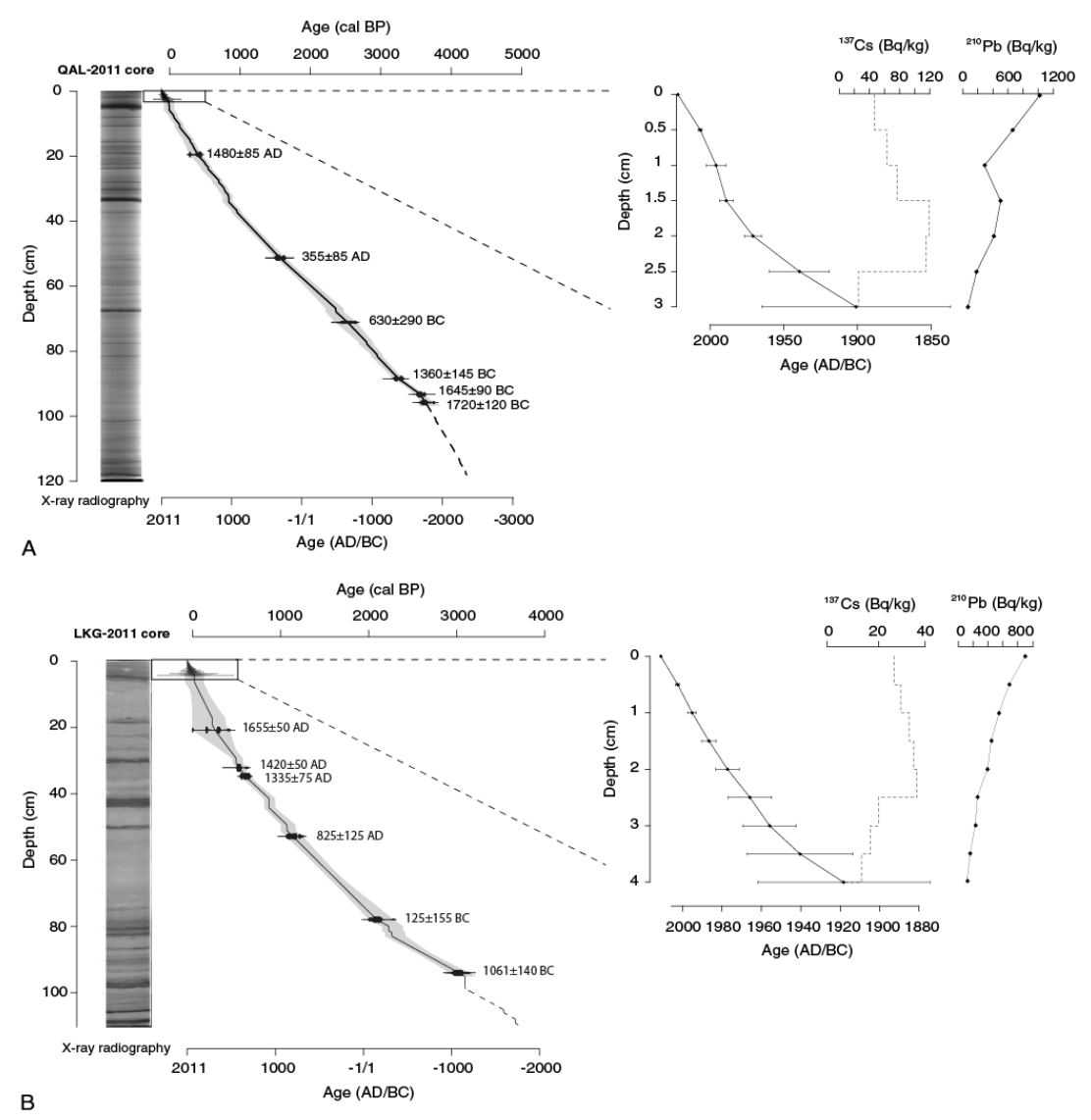

Figure 2. Age-depth models based on radiocarbon dates and on short-lived radio-isotopes measurements. (a) Lake Qallimiut age-depth model. (b) Lake Little Kangerluluup age-depth model.

\section{CPD}

$11,5401-5438,2015$

\section{Impact of Holocene climate variability}

T. Guillemot et al.

\section{Title Page}

\begin{tabular}{c|c}
\hline Abstract & Introduction \\
\hline Conclusions & References \\
\hline Tables & Figures \\
\hline In & \\
\hline 14 & $>$ । \\
\hline 4 & $\triangleright$ \\
\hline Back & Close \\
\hline
\end{tabular}

Full Screen / Esc

Printer-friendly Version

Interactive Discussion

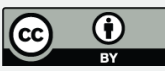




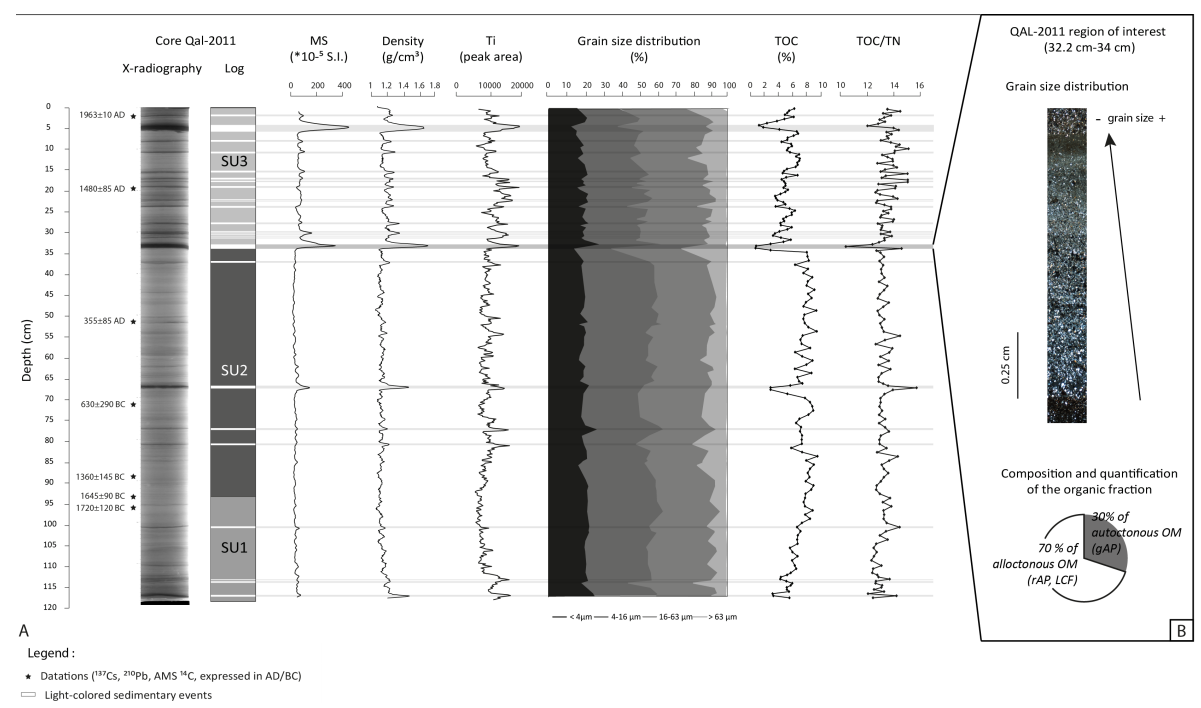

Figure 3. (a) X-radiographs and log representing the Lake Qallimiut core associated to magnetic susceptibility, $\gamma$-density, XRF, grain size, TOC and TOC/TN ratio measurements. Grey zones highlight the physical and geochemical responses of the white laminae. (b) The frame contains photographs of the thin section in polarized light and the piechart shows the composition of the OM.
CPD

$11,5401-5438,2015$

\section{Impact of Holocene climate variability}

T. Guillemot et al.

Title Page

\section{Abstract}

Introduction

Conclusions References

Tables

Figures

14

$\Delta$

4

Back

Close

Full Screen / Esc

Printer-friendly Version

Interactive Discussion

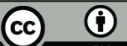




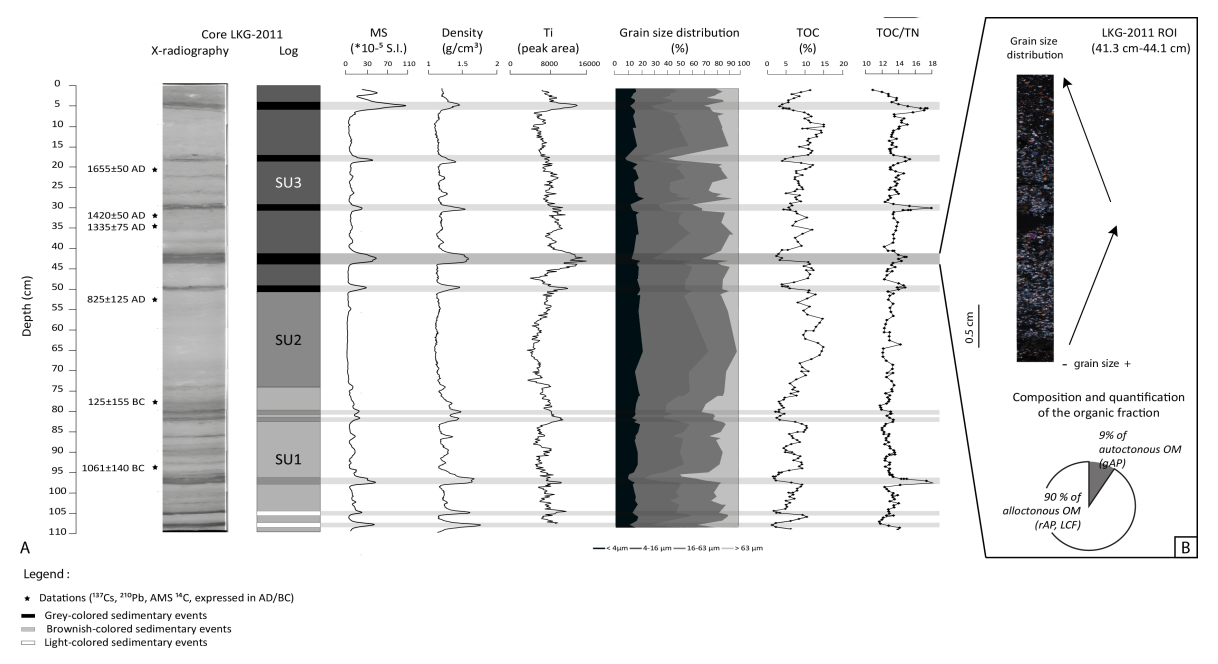

Figure 4. (a) X-radiographs and log representing the Lake Little Kangerluluup core associated to magnetic susceptibility, $\gamma$-density, XRF, grain size, TOC and TOC/TN ratio measurements. Grey zones highlight the physical and geochemical responses of the laminae. (b) The frame contains photographs of the thin section in polarized light and the piechart shows the composition of the OM in pies.

\section{CPD}

$11,5401-5438,2015$

\section{Impact of Holocene climate variability}

T. Guillemot et al.

Title Page

\section{Abstract}

\section{Introduction}

Conclusions References

Tables

Figures

14

$\rightarrow 1$

4

Back

Close

Full Screen / Esc

Printer-friendly Version

Interactive Discussion

(c) (1) 


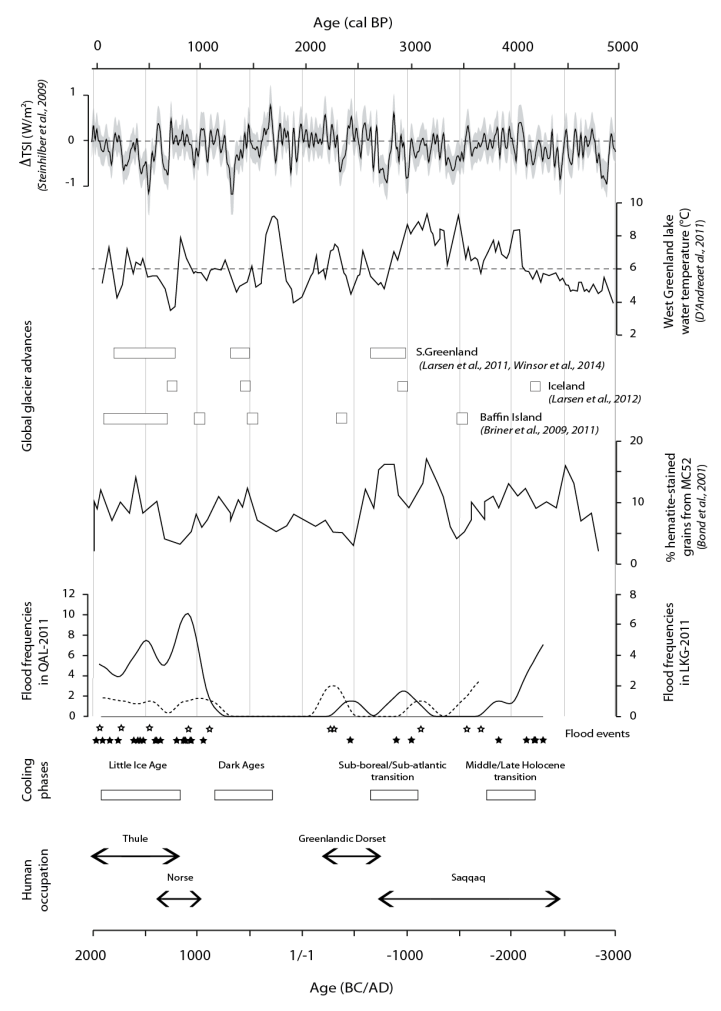

Figure 5. Flood frequencies expressed in a time step of 250 years in the last four millennia. In black, flood frequency measured in Qallimiut sequence and in dotted line, flood frequency observed in Little Kangerluluup core. They are compared to solar irradiance (Steinhilber et al., 2009), west Greenland lake water temperatures (D'Andrea et al., 2011), global glacier advances (Briner et al., 2011, 2009; Kelly et al., 2008; Larsen et al., 2011; Winsor et al., 2014), the main rapid climate changes (Mayewski et al., 2004) and periods of Human occupations (Dugmore et al., 2009; Gulløv, 2004; Jones, 1986; Meldgaard, 2004).

\section{CPD}

$11,5401-5438,2015$

\section{Impact of Holocene climate variability}

T. Guillemot et al.

Title Page

\section{Abstract}

Introduction

Conclusions References

Tables

Figures

14

$\triangle 1$

4

Back

Close

Full Screen / Esc

Printer-friendly Version

Interactive Discussion 


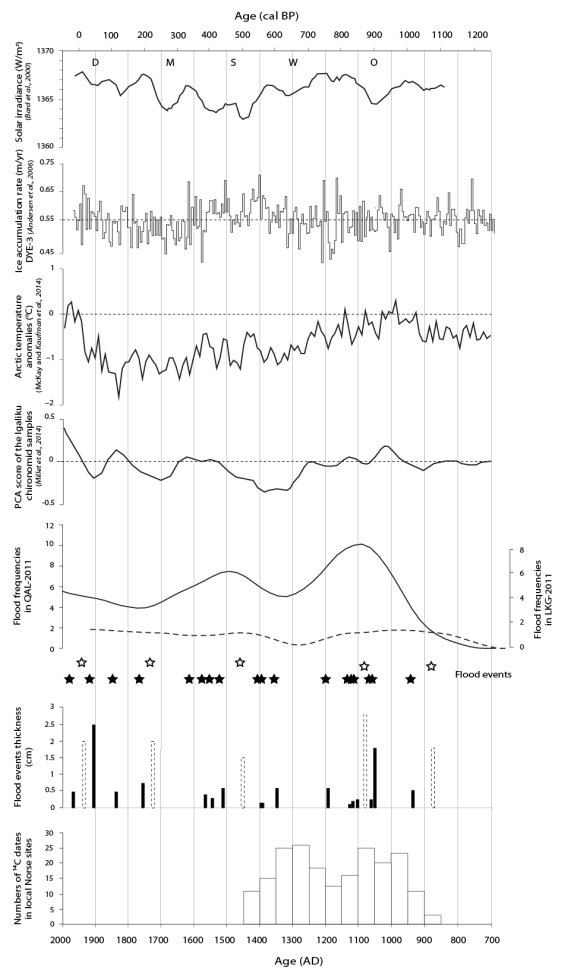

Figure 6. Focus on Qallimiut and Little Kangerluluup flood frequencies in the last millennium. They are associated to their thickness (in black, Qallimiut flood deposit thickness and in dotted line, Little Kangerluluup flood events thickness). They are also compared to solar irradiance (Bard et al., 2000), ice accumulation rate (Andersen et al., 2006), Arctic temperature anomalies (McKay and Kaufman, 2014), PCA score of the Igaliku chironomid samples (Millet et al., 2014) and the number of radiocarbon dates measured in local archaeological sites (Arneborg, 2007; Edvardsson et al., 2007; Madsen et al., 2009; Arneborg et al., 2012).

\section{CPD}

$11,5401-5438,2015$

\section{Impact of Holocene climate variability}

T. Guillemot et al.

\section{Title Page}

\section{Abstract}

Introduction

Conclusions References

Tables

Figures

14

$\rightarrow 1$

4

Back

Close

Full Screen / Esc

Printer-friendly Version

Interactive Discussion 